\title{
Şamlı (Balıkesir) Demir Madeni Doğu Ocağı Batı Şevlerini Oluşturan Kaya Kütlelerinin Duraylılık Değerlendirmesi
}

Slope Stability Assessment of Rock Masses in Western Sector of Balıkesir Şamlı Eastern Open Pit Iron Mine

\section{Dinçer ÇAĞLAN ${ }^{1}$, Levent TOSUN ${ }^{2}$, Serdar Onur AVCI ${ }^{1}$, Oğuz TURUNÇ ${ }^{1}$, Gökhan KANAAT ${ }^{1}$}

${ }^{1}$ Demir Export A.Ş., Maden Arama Müdürlügü̈, Kızılay/ANKARA

${ }^{2}$ Orta Doğu Teknik Üniversitesi, Jeoloji Mühendisliği Bölümü, ANKARA

$\begin{array}{lll}\text { Geliş (received) } & : & 09 \text { Aralı (December) } 2015 \\ \text { Düzeltme (revised) } & : & 15 \text { Şubat (February) } 2016 \\ \text { Kabul (accepted) } & : & 26 \text { Şubat (February) } 2016\end{array}$

ÖZ

Eklemli kayaç kütleleri üzerinde inşa edilmiş mühendislik yapılarında, şev duraylılığ 1 , sağlam kayacın dayanım parametrelerinden çok, süreksizliklerin dayanım parametreleriyle denetlenmektedir. Ayrıca süreksizliklerin dayanımını denetleyen başlıca parametrelerin, süreksizliklerin açıklı̆̆ı, devamlılıkları, yüzey pürüzlülükleri, içerdikleri dolgunun kalınlığ1 ve türü olduğu bilinmektedir. Bu çalışmada, Balıkesir-Şamlı Doğu Açık Ocağı'nda haritalanan hornfelsler içerisinde gelişmiş dolgu içermeyen süreksizliklerin Barton görgül yenilme ölçütü kullanılarak, makaslama dayanım parametreleri belirlenmiştir. Süreksizliklerin konumları ve makaslama dayanım parametreleri kullanılarak yapılan kinematik analizlerle, şevlerin kayma potansiyelleri belirlenmiştir. Belirlenen yenilme tiplerine göre duraylılık analizleri gerçekleştirilmiş, Şamlı Doğu Ocağı batı şevlerinin eğim yönlerinin kuzey kanadında $218^{\circ}$, güney kanadında ise $15^{\circ}$ olarak açılması, basamak şev açılarının; W3 bozunma bölgelerinde $65^{\circ}$, W3-W4 bozunma bölgelerinde ise $60^{\circ}$ olacak şekilde oluşturulması gerektiği sonucuna varılmıştır.

Anahtar Kelimeler: Açık Ocak Demir Madeni, Barton Görgül Yenilme Ölçütü, Kinematik Analiz, Şev Duraylılığı.

\section{ABSTRACT}

The slope stability of rock masses which the engineering constructions build on is controlled by the strength parameters of discontinuity surfaces rather than shear strength parameters of rock bodies. In addition, it is known that the aperture, persistence, roughness, and if it presents, thickness and type of

D. Çağlan

E-posta:dincerc@demirexport.com 
Çağlan, Tosun, Avcı, Turunç, Kanaat

infill materials are the major parameters which control the strength of discontinuities. In this study, the shear strength parameters of discontinuities in the hornfels lithology in the Doğu Ocak (eastern sector of Balıkesir-Şaml-Iron Open Pit Mine) were determined by using the Barton empirical failure criterion. The probable rock slope failure modes were established by means of kinematic analyses performed considering the orientations and shear strength parameters (cohesion and internal friction angle) of discontinuity surfaces. It is proposed that the orientation of the slopes are $218^{\circ}$ in northern side and $15^{\circ}$ in southern side whereas bench slopes are $65^{\circ}$ and $60^{\circ}$ in $W 3$ and W3-W4 weathering zones respectively, in accordance with the stability analyses performed in the light of the information obtained from the models in the Doğu Ocak.

Key Words: Iron Open Pit Mine, Barton Empirical Failure Criterion, Kinematic Analyses, Slope Stability.

\section{GíRiş}

Yeraltı ve yerüstü madenlerinin işletilmeleri sırasında ortaya çıkabilecek her türlü güvenlik zafiyeti geri dönülemez sonuçlar doğurmaktadır. $\mathrm{Bu}$ nedenle, olası kazalara karşı gerekli tüm güvenlik önlemleri büyük bir titizlikle alınmalıdır. Güvenli bir açık ocak, işletmenin devamlılığının ve ekonomikliğinin sürdürebilmesinin başlica güvencesidir ve yürütülen şev duraylılığ1 çalışmaları ocak güvenliğinin sağlanabilmesi için yapılan çalışmaların başında gelir.

Şamlı demir ocağı, Balıkesir'in kuzeyinde yeralmaktadır. Balıkesir'e 30 km, Şamlı lçesine 4 km uzaklıktadır (Şekil 1).

1973 y1lından itibaren işletilen Şamlı Demir Cevheri İşletmesi'nde, bugüne kadar 2 milyon ton demir cevheri üretimi gerçekleştirilmiştir. Geriye kalan demir cevheri rezervi yaklaşı 2 milyon tondur ve $\% 57$ demir $(\mathrm{Fe})$ içeriğine sahiptir. Ana cevher minerali manyetit olan işletmenin yıllık üretim kapasitesi 200.000 tondur.
Şamlı demir işletmelerinde Doğu ve Bat1 Ocakları olmak üzere iki ocakta üretim yapılmaktadır. 2016 yıllının son çeyreğinde Şamlı Doğu Ocağı'nın batıya doğru ilerlemesi sağlanarak Doğu ve Batı ocaklarının birleştirilmesi planlanmaktadır. Oluşturulacak batı şevlerinin basamak şev yükseklikleri $10 \mathrm{~m}$, basamak şev açıları $70^{\circ}$ ve basamak genişlikleri $6 \mathrm{~m}$ olarak planlanmaktadır. Ancak doğu ocağı içerisinde mevcut şev açılarının $70^{\circ}$ 'nin üstünde olduğu bölgeler belirlenmiş ve basamak bazında süreksizlik denetimli gelişen duraysızlıklar saptanmıştır. Duraysızlıklar genelde düzlemsel kayma şeklindedir ve yersel olarak kama tipi kaymalar da gözlenmektedir. Bu çalışmanın amacı, açık ocak kaya şevlerindeki duraysızlıkların oluşum mekanizmalarını araştırmak, duraysızlıklara neden olan süreksizliklerin jeoteknik özelliklerini saptamak ve oluşturulacak batı şevleri için duraylı şev geometrilerini belirlemektir. 


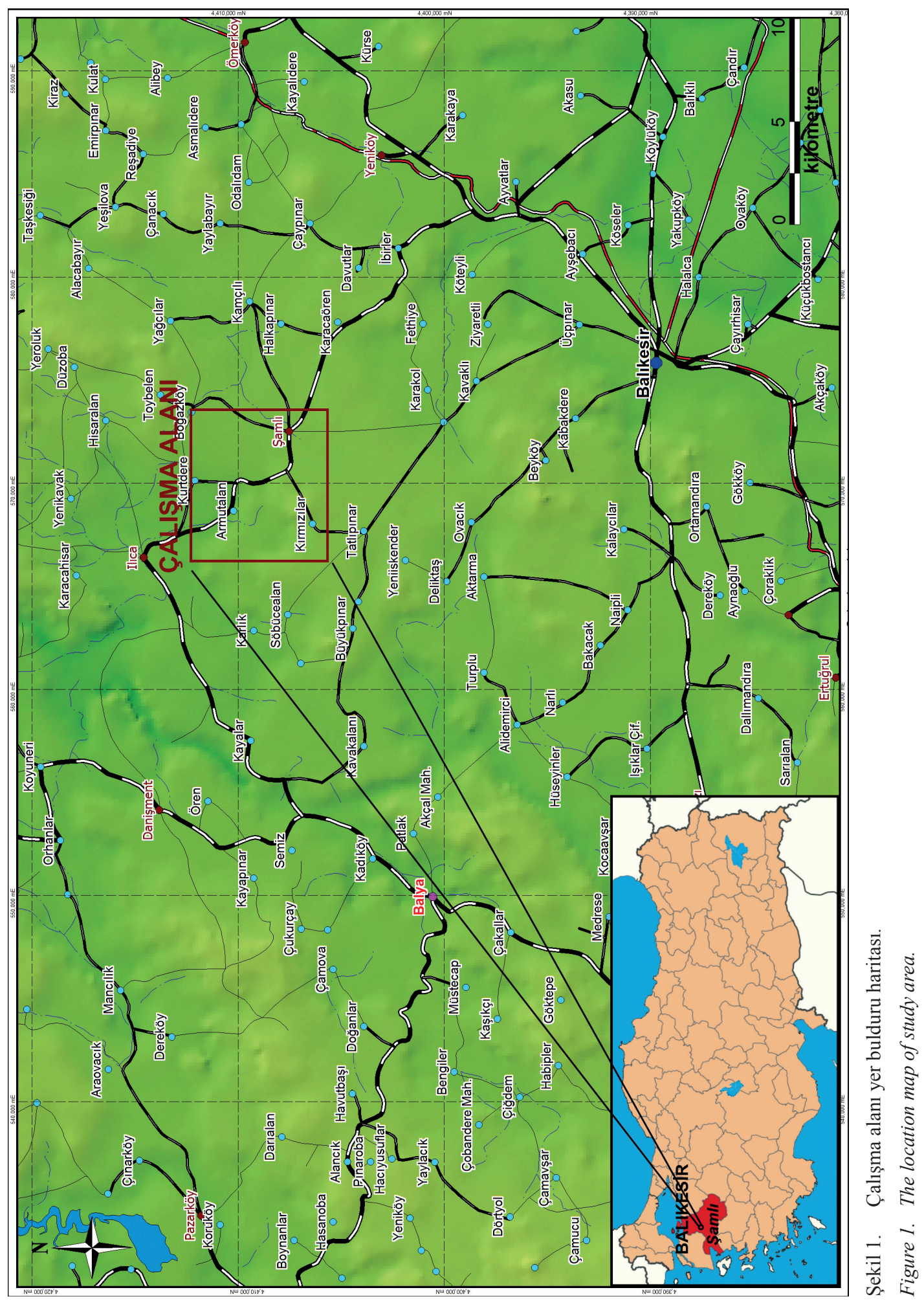


Çağlan, Tosun, Avcı, Turunç, Kanaat

\section{YÖNTEMLER}

Çalışma alanındaki süreksizlik denetimli duraysızlıkların engellenebilmesi için öncelikle süreksizliklerin dayanım parametrelerinin belirlenmesi amaçlanmıştır. $\mathrm{Bu}$ amaçla çalışma alanının mühendislik jeolojisi haritası hazırlanmış, hat etütleri yapılmış, süreksizlik yüzeylerine Schmidt çekici uygulanmış ve telli profilometre yardımıyla pürüzlülük profilleri çıkarılmıştır. Bu veriler yardımıyla Barton görgül yenilme ölçütü (Barton ve Choubey, 1977) yardımıyla süreksizlik yüzeylerinin dayanım parametreleri hesaplanmıştır.

Elde edilen dayanım parametreleri kullanılarak kinematik ve duraylılık analizleri gerçekleştirilmiştir. Analizlerde Rocscience firması tarafından geliştirilen, kinematik analizler için Dips 6.0 (RocScience, 2015a), düzlemsel kaymalar için RocPlane 3.0 (RocScience, 2015b) ve kama tipi kaymalar için ise Swedge 6.0 (RocScience, 2015c) programları kullanılmıştır. Kinematik analizlerde, düzlemsel ve devrilme türü duraysızlıklar için süreksizliklerin kutup noktaları, kama türü analizlerde ise süreksizliklerin büyük daireleri ile çalışılmıştır. Kama türü kaymaların duraylılık analizlerinde, kayma potansiyeli olan süreksizliklerden en riskli olan süreksizlere ait eğim açısı/eğim yönü değerleri kullanılmıştır.

Dips 6 programında, düzlemsel kaymaların kinematik analizleri kutup noktaları kullanılarak yapılmaktadır. Yüzlek zarfı içerisinde yer alan riskli zon içerisine düşen noktaların, süreksizliklerin kutup noktaları olması sebebiyle, içsel sürtünme açısı konisi, stereonetin merkezi
" 0 " " kabul edilerek çizilmektedir. Kama tipi yenilmelerin kinematik analizlerinde kaymaya neden olabilecek süreksizliklerin ve şevlerin büyük daireleri ile analiz yapıldığından içsel sürtünme açısı konisi, stereonetin dış çemberi " 0 " " kabul edilerek çizilmektedir. (RocScience, 2015a). Yüzlek zarfı pratikte, şevin büyük dairesini kesen olası tüm süreksizliklerin kutup noktalarının oluşturduğu bölgeyi belirleyen zarfa verilen isimdir (Lisle, 2004). Yüzlek zarfı içinde kalan ve kinematik anlamda düzlemsel kayma koşullarının sağlandığı alan ise riskli bölge olarak tanımlanmaktadır.

\section{BÖLGENIN GENEL JEOLOJISİ}

Balıkesir-Şamlı demir madeni sahası Kuzeybatı Anadolu'da Anatolitler içerisinde yer almaktadır. Çalışma alanı ve yakın civarında gözlenen en yaşlı kaya birimi Alt Triyas yaşlı Kınık Formasyonu'dur. Formasyon, yeşilşist fasiyesinde düşük metamorfizma geçirmiş kumtaş1, çamurtaş1, kiltaş1, kireçtaş1 ve diyabaz, spilit gibi volkanik kayaçlardan oluşur. Birim içerisinde Üst Permiyen yaşlı kireçtaşı blokları da yer alır. Kınık Formasyonu Alt Miyosen yaşlı yer yer porfiritik doku özellikleri sunan Şamlı Plutonu tarafından kesilir. Şamlı Plutonu KKD-GGB uzanım sunmaktadır. Bu plutonun felsik ve mafik olmak üzere iki farklı fazdan oluştuğu ifade edilmektedir (Yılmazer vd., 2014). Felsik faz kuvars monzonit, monzogranit, granodiyorit ve granit porfir, mafik faz ise diyorit ve diyoritporfirler ile temsil edilmektedir. Çalışma alanında geniş bir yayılım sunan hornfelsler, Şamlı Plutonu'nun karbonatlı yan 
kayaçlar ile intrüsüf ilişkisi sonucu oluşmuş skarn zonlarında gözlenir. Çalışma alanındaki en genç birimler olan ve genellikle volkanik ara katkı1ı kireçtaşlarıyla temsil edilen Bigadiç Formasyonu ile yanal devamlılı sunan Orta-Üst Miyosen yaşlı Yuntdağ Volkanitleri ise karasal ortamda, lav, aglomera ve tüf ardalamasindan oluşmaktadır. Yuntdağ Volkanitleri tüm birimleri uyumsuz üstler konumdadır.

Cevherleşme, Şamlı Graniti'nin Kınık Formasyonu'na ait kaya birimlerini kesmesi sonucu, her iki kayaç dokanağında oluşan skarn zonu içerisinde izlenmektedir. Skarn zonu, kalk silikat mineralleri (granat, epidot, klorit, aktinolit) ile manyetit, hematit, az oranda pirit ve kalkopiritli cevher minerallerinden oluşmaktadır. Cevher mineralleri skarn zonu içerisinde masif mercek, bant, damar ve saçınımlı olarak izlenmektedir. Skarnlaşma sonrasında andezit bileşimli ve kalınlığg 1-20 m arasında değişen magmatik aktivite (olası Şamlı granitinin son fazı) tüm sistemi katetmektedir.

\section{DEPREMSELLIKK}

Çalışma alanının da içinde yer aldığı Biga Yarımadası'nı etkileyen doğal afetler arasında depremler ilk sırada yer almaktadır. İnceleme alanı, Bakanlar Kurulu'nun 18.04.1996 tarih ve 96/8109 sayılı kararı ile yürürlüğe giren Deprem Bölgesi Haritası'na göre I. derece deprem bölgesi içinde yer almaktadır (Deprem Araştırma Dairesi Başkanlığ1, 1996). Tarihsel ve aletsel dönemde, bölgede can kayıplarına ve hasarlara neden olan çok sayıda orta ve büyük ölçekli depremler meydana gelmiştir.

Çalışma alanında ve yakın çevresinde etkili olan depremler, Yenice-Gönen Fay Zonu ve Balıkesir Fayı'nın Kepsut ve Gökçeyazı segmentlerinde meydana gelmiştir (Şekil 2). Yenice-Gönen Fay Zonu, kuzeydoğuda Gönen göneybatıda Yenice ilçeleri boyunca toplam 67 km uzunluğunda olup, K65D genel doğrultuludur (Emre vd., 2012). Magnitüdü 7.2 olan, 1953 y1lı Yenice-Gönen depremiyle oluşmuş yüzey kırıkları Yenice-Gönen arasında ilk defa Herece (1985) tarafindan ayrıntılı olarak haritalanarak Yenice-Gönen Fayı olarak adlandırılmıştır (Sarı vd., 2010). Havran-Balıkesir Fay Zonu, Biga Yarımadası'nın Güneydoğusu'nda Balıkesir il sınırları içinde, Edremit Körfezi ile Kepsut arasında uzanan sağ yönlü doğrultu atımlı aktif fay sistemidir (Emre vd., 2012). Tarihsel ve aletsel dönem kayıtlarında Havran-Balya Fayı'nda büyük depremler geliştiğine ilişkin bilgiler mevcut değildir. Balıkesir Fayı; İvrindiKepsut ilçeleri arasında D-B genel doğrultusunda güneye doğru iç bükey olarak uzanır. Balıkesir Fayı'nın yaşı ve toplam atımı hakkında kesin bir veri yoktur (Emre vd., 2012). Çalışma alanının yakınında, Maden Tetkik Arama (MTA) verilerine göre aktif olan (MTA, 2012) KB-GD uzanımlı Şamlı fayı yer almaktadır. Tarihsel ve aletsel dönemde deprem ürettiğine dair yazılı bir belge bulunmamakla birlikte, Güler ve Ceryan (2015)'e göre bu fay, Büyüklüğü 6.0 olan bir deprem üretebilecektir. 


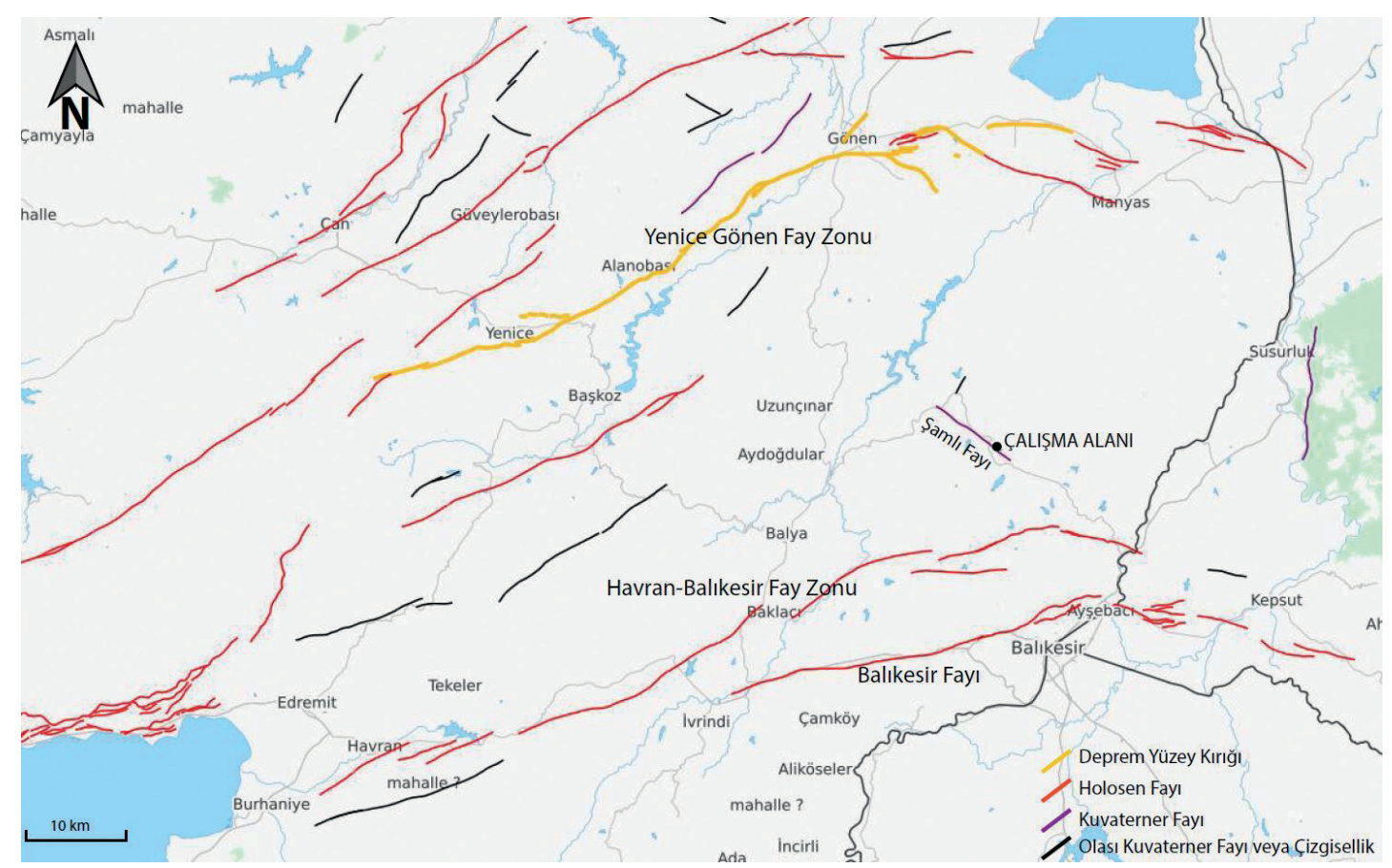

Şekil 2. Çalışma alanı ve yakın civarının diri fay haritası (MTA, 2012).

Figure 2. Active fault map of the study area and its close vicinity.

\section{JEOTEKNİK ÇALIŞMALAR}

Bu çalışmada, Şamlı Doğu Ocağı'nın mevcut basamaklarında gözlenen ve kaya özelliği taşıyan birimlerin jeoteknik özellikleri ele alınmıştır. Kaya birimlerinin duraylılık analizlerinde girdi olarak kullanılacak parametrelerin saptanabilmesi amaciyla mühendislik jeolojisi harita alım çalışmalarıyla eş zamanlı olarak basamaklarda gelişmiş duraysızlıklar üzerinde gözlemler yapılmış ve süreksizlik hat etüt çalışmaları gerçekleştirilmiştir.

\section{Mühendislik Jeolojisi Haritası}

Çalışma alanında, mevcut kayaç grupları üzerinde gelişmiş bozunma zonlarını gösteren 1/1000 ölçekli ayrıntılı mühendislik jeolojisi haritası hazırlanmıştır (Şekil 3). Bozunmaların derinliğini ve yayılımlarını belirlemek için rezerv amaçlı olarak yapılan sondajlardan da yararlanılmıştır. Sahada kaya birimlerinin büyük bölümünün ISRM (1981)'e göre orta (W3) ve ileri derecede bozunmuş (W4) oldukları belirlenmiştir. Ocağın bazı kesimlerinde bozunma derecelerinin çok kısa aralıklarla değişmesi nedeniyle ayırtlanamayan bölgeler, her iki bozunma simgesi birlikte kullanılarak haritalanmıştır. Harita alım çalışmaları sırasında yapılan arazi gözlemlerinde genel olarak ocağın güney kesimindeki kaya birimlerinin, kuzey kesimindeki kaya birimlerine oranla daha fazla bozundukları saptanmıştır. Süreksizliklik yüzeylerinin ayrışmaları ile ilgili yorumlar, kaya kütlesinin bozunma derecesi ile ilişkendirilerek yapılmaya çalışılmıştır. 


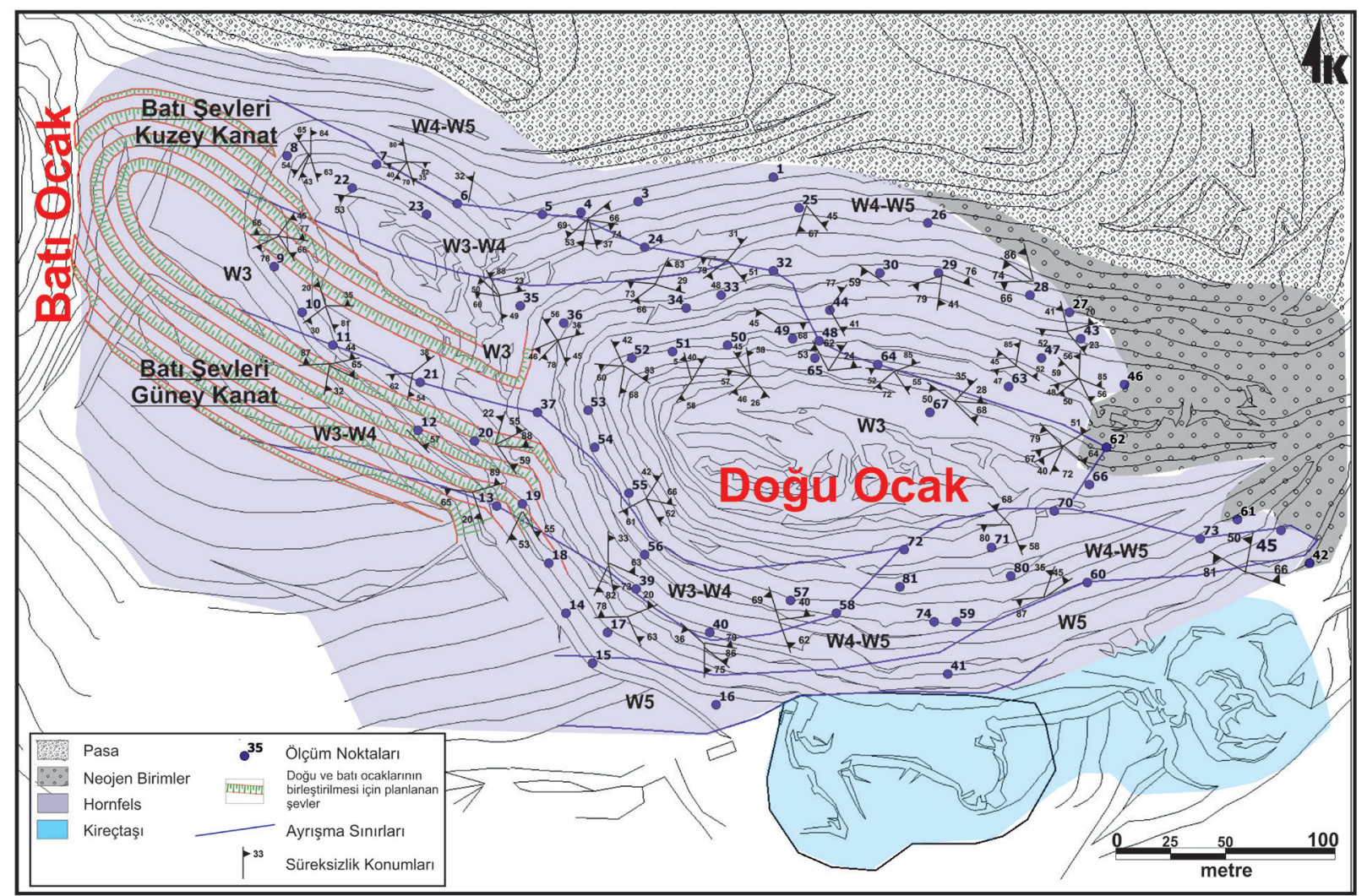

Şekil 3. Ş̧amlı Doğu Ocağı'nın mühendislik jeolojisi haritası.

Figure 3. The engineering geological map of the Şamlı Doğu Ocak.

\section{Süreksizlik Hat Etüitleri}

Çalışma alanı içerisinde gözlenen baskın litoloji killi ve karbonatlı sedimanter kayaçların kontak metazomatizma ürünü olan hornfelslerdir. Birimlerin kaya özelliği göstermeleri, oluşturulması planlanan şevlerde gelişebilecek olası duraysızlıkların süreksizlik denetimli olabileceğine işaret eder. Arazi gözlemleri de, kaya birimlerinde gelişen duraysızlıkların süreksizlik denetimli olduğunu göstermektedir. $\mathrm{Bu}$ nedenle kaya birimlerde, süreksizliklerin aşağıda sıralanan özelliklerinin saptanabilmesi amacıyla süreksizlik hat etütleri gerçekleştirilmiştir. Süreksizlik özelliklerinin tanımlanmasında Ulusay ve Sönmez (2007)'den yararlanılmıştır.

Süreksizliklerin devamlılıkları gözle, pürüzlülükleri ise tel profilometre yardımıyla belirlenmiştir. Ayrıca süreksizlik yüzeylerinin dayanımını belirleyebilmek için L tipi Schmidt Çekici kullanılmıştır (Şekil 4). 
Çağlan, Tosun, Avcı, Turunç, Kanaat

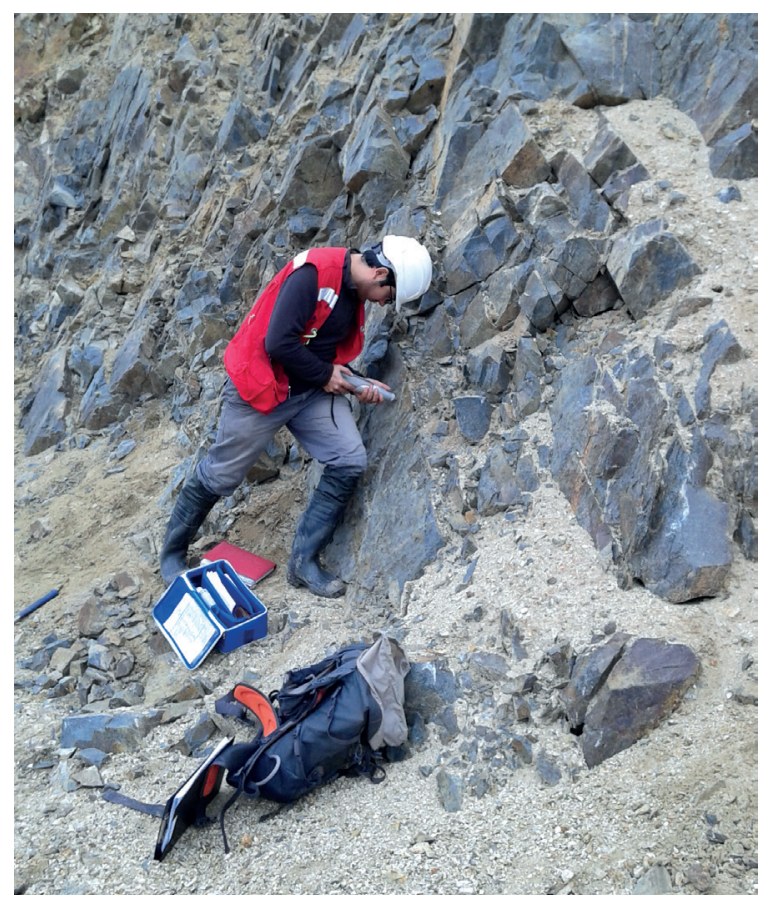

Şekil 4. Schmidt çekici uygulaması.

Figure 4. Application of Schmidt hammer in the field.

Yapılan çalışmalar sonucunda süreksizliklerin genel özellikleri Çizelge 1'de sunulmuştur.

Çizelge 1. Çalışma alanındaki süreksizliklerin özellikleri.

Table 1. The characteristics of the discontinuities in the study area.

\begin{tabular}{|l|l|}
\hline $\begin{array}{l}\text { Süreksizliğin türü (Eklem, } \\
\text { Tabaka, Fay vd.) }\end{array}$ & Eklem \\
\hline $\begin{array}{l}\text { Süreksizliklerin yönelimi } \\
\text { (Eğim açısı/ eğim yönü) (iki } \\
\text { ana eklem sisteminin) }\end{array}$ & $\begin{array}{l}70 / 183 \\
60 / 061\end{array}$ \\
\hline Süreksizlik açıklıkları & $1-5 \mathrm{~mm}$ \\
\hline Süreksizlik aralığ1 & $20-150 \mathrm{~cm}$ \\
\hline Pürüzlülük (JRC) & $4-14$ \\
\hline Dalgalılık & $\begin{array}{l}\text { Az dalgalı (Golder } \\
\text { Assocates, 1979) }\end{array}$ \\
\hline Devamlılık & $>20 \mathrm{~m}$ \\
\hline Dolgu & $\begin{array}{l}\text { Dolgusuz (yer yer kalsit } \\
\text { dolgulu) }\end{array}$ \\
\hline Su sızıntısı & Kuru \\
\hline
\end{tabular}

Mühendislik jeolojisi harita alım çalışmaları sırasında ayırtlanan bozunma zonlarındaki süreksizlik yüzeylerinin dayanım parametrelerinin (kohezyon ve içsel sürtünme açıs1) hesaplanmasında, Barton görgül yenilme ölçütü (Barton ve Choubey, 1977) kullanılmıştır. Çalışmalar sırasında süreksizlik yüzeylerinde yapılan Schmidt Çekici uygulamaları Barton ve Choubey (1977)'nin önerdiği şekilde yapılmıştır. Schmidt sertlik değerlerinin (R), süreksizlik yüzeylerinin bozunma derecelerine ve pürüzlüklerine bağ l1 olarak değişkenlik gösterdiği ve 16-65 arasında değiştiği belirlenmiştir.

Ayırtlanan bozunma bölgelerine göre ortalama Schmidt sertlik değerleri; W4 bozunma bölgesinde 22.4, W3-W4 bozunma bölgesinde 43.5 ve W3 bozunma bölgesinde 51.6 olarak bulunmuştur. Süreksizlik yüzeyinin pürüzlülük katsayısı değerleri (JRC), Barton ve Choubey (1977) tarafından önerilen abaktan karşılaştırma yapılarak bulunmuştur (Şekil 5). Her bozunma bölgesi için JRC değerlerinin 4-14 arasında değiştiği saptanmıştır. Yapılan çalışmalarda, JRC değerlerinin, bozunma derecelerine bağlı bir değişim gösterdiğine yönelik anlamlı bir ilişki görülememiştir. Batı şevlerinde, özellikle duraysızlığa neden olan süreksizlik yüzeylerinin pürüzlülüklerinin görece arttığ1 belirlenmiştir. Belirlenen JRC değerleri, çalışmalarda kolaylık sağlaması amaciyla bulunan değerlerin ortalamaları alınarak 5,8 ve 12 olarak sinıflandırılmıştır. 


\begin{tabular}{|l|l|}
\hline & $J R C=0-2$ \\
\hline & $J R C=2-4$ \\
\hline & $J R C=4-6$ \\
\hline & $J R C=6-8$ \\
\hline & $J R C=8-10$ \\
\hline & $J R C=10-12$ \\
\hline & $J R C=12-14$ \\
\hline & $J R C=14-16$ \\
\hline & $J R C=16-18$ \\
\hline & $J R C=18-20$ \\
\hline
\end{tabular}

Şekil 5. Barton pürüzlülük abağ1 (JRC: Pürüzlülük katsay1s1) (Barton ve Choubey, 1977).

Figure 5. Rockjoint roughness profiles showing the typical range of JRC (Barton and Choubey, 1977).

\section{Duraysızlıklara İlişkin Gözlemler}

Şamlı Doğu Ocağı'nda, basamak şev açılarının yer yer $70^{\circ}$ ve üstünde açıldığ 1 gözlenmiş ve hemen hemen tüm şevlerde kaya birimler içinde basamak bazında düzlemsel (Şekil 6a) ve kama tipi (Şekil 6b) kaymaların

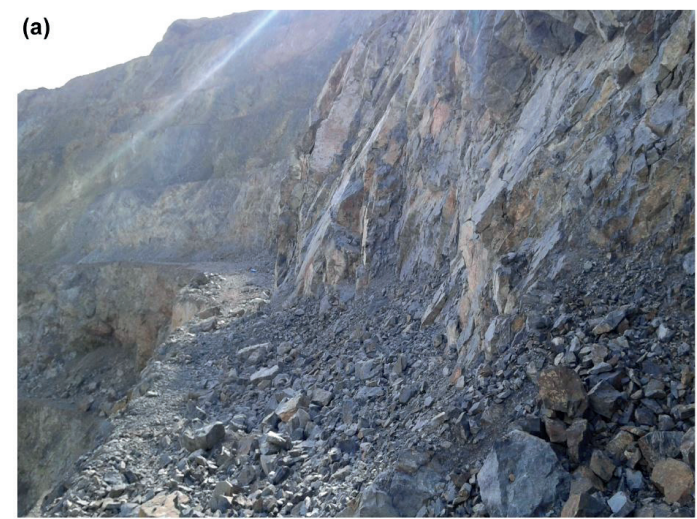

yaygın olarak geliştiği belirlenmiştir. Ayrıca, ocağın basamak şev açılarının çoğunlukla düzlemsel kaymalar tarafindan kontrol edildiği gözlenmiştir.

Arazi çalışmaları sırasında belirlenen 35 düzlemsel kaymanın, 7 tanesinde, kaymaya neden olan süreksizlik açısının $(\alpha) 70^{\circ}$ 'den, 11 tanesinin ise $60^{\circ}$ 'den büyük olduğu saptanmıştır. Kalan 17 duraysizlıkta ise kaymalara neden olan süreksizlik açısı değerlerinin $40^{\circ}$ ile $59^{\circ}$ arasında değiştiği belirlenmiştir. Ayrıca, süreksizlik açısı $50^{\circ}$ 'nin altında olan kaymaların hemen hemen tamamının, bozunma derecesine bakılmaksızın, pürüzlülük katsayıları düşük olan $(\mathrm{JRC}=4-6)$ süreksizlikler boyunca geliştiği belirlenmiştir.

Çalışma alanında gözlenen kama tipi kaymaların genelde küçük boyutlu, sadece bir basamağ1 kapsayacak şekilde ve çoğunlukla Doğu Açık Ocă̆ı'nın kuzey şevlerinde geliştiği gözlenmiştir. Şekil 6b'de görülen duraysızlık ocak içerisindeki en belirgin kama tipi kaymadır ve gelişen diğer kaymalar bu kaymanın yanında çok daha küçük boyutludur.

Arazi çalışmaları sırasında açık ocakta devrilme türü duraysızlık gözlenmemiştir.

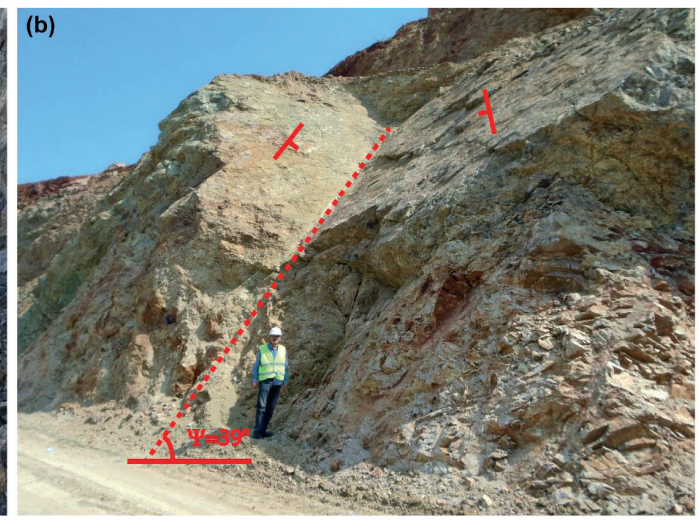

Şekil 6. Ocak içinde gözlenen a) düzlemsel kaymalar b) kama tipi kayma.

Figure 6. Rock failure observed in cutting surfaces, a) planar sliding, b) wedge sliding. 
Çağlan, Tosun, Avcı, Turunç, Kanaat

\section{Süreksizlik Yüzeylerinin Dayanım Parametrelerinin Hesaplanması}

Süreksizliklerin makaslama dayanım parametrelerinin hesaplanmasinda Barton (1973) tarafından önerilen aşağıdaki görgül yenilme ölçütü eşitliği kullanılmıştır.

$\tau=\sigma_{\mathrm{n}} \tan \left[\mathrm{JRC} \log _{10}\left(\mathrm{JCS} / \sigma_{\mathrm{n}}\right)+\Phi_{\mathrm{b}}\right]$

Eşitlikte;

$\tau$ : doruk makaslama gerilmesi

$\sigma_{\mathrm{n}}:$ normal gerilme

JRC: süreksizlik yüzeyinin pürüzlülük katsayıs1

JCS: süreksizlik yüzeyinin tek eksenli sıkışma dayanım 1

$\Phi_{\mathrm{b}}$ : temel içsel sürtünme açısı

Barton ve Choubey (1977), çalışmalarında Schmidt Çekici ile elde edilen verilere dayanarak, eklem yüzeylerinin Tek Eksenli Sıkışma Dayanımları'nın $\left(\sigma_{c}\right)$ (JCS) hesaplanmasında aşağıdaki eşitliğin güvenilir sonuçlar verdiğini belirtmiştir.

$\log _{10}\left(\sigma_{c}\right)=0.00088 \mathrm{~g} \mathrm{R}+1.01$

Eşitlikte;

$\sigma_{\mathrm{c}}(\mathrm{JCS}):$ Eklem yüzeyinin tek eksenli sıkışma dayanımı $(\mathrm{MPa})$

g : Kayacın kuru birim hacim ağırlığ $1\left(\mathrm{kN} / \mathrm{m}^{3}\right)$

R: Schmidt sertlik değeri

$\mathrm{Bu}$ eşitlikte yer alan parametrelerden JRC ve JCS, arazi çalışmalarından elde edilen verilerle hesaplanmıştır. Eşitlik (1) de yer alan $\Phi_{\mathrm{b}}$ ise metamorfik kayaçlar için önerilen değerler dikkate alınarak $28^{\circ}$ (Barton ve Choubey, 1977) olarak kabul edilmiştir. Birim hacim ağırlık $\left(g_{n}\right)$ değerleri ise, bozunma dereceleri göz önüne alınmadan, sondajlardan alınan karot örnekleri üzerinde yapilan deneyler sonucunda ortalama $26.6 \mathrm{kN} / \mathrm{m}^{3}$ olarak bulunmuştur.
Arazi çalışmalarında ayırtlanan her bölge için, (1) numaralı eşitlik kullanılarak farklı normal gerilmelere ait makaslama değerleri hesaplanmıştır. $\mathrm{Bu}$ veriler kullanılarak çizilen grafikten elde edilen “ $\boldsymbol{\sigma}_{\mathbf{n}} \boldsymbol{\tau} \boldsymbol{\tau}$ " zarfi yardımıla süreksizliklere ait genelleştirilmiş kohezyon ve içsel sürtünme açısı değerleri belirlenmiştir (Şekil 7). Barton tarafindan önerilen yenilme ölçütünde “ $\boldsymbol{\sigma}_{\mathbf{n}}-\boldsymbol{\tau} "$ zarfinın eğrisel olduğu bilinmektedir (Barton ve Choubey, 1977). Ancak, Şekil 6 incelendiğinde, elde edilen zarfın doğrusal olduğu görülmektedir. Barton ve Choubey (1977)'nin yaptıkları çalışmalar sonucu hazırladıkları grafikler incelediğinde, pürüzlülük azaldıkça makaslama gerilmelerinin eğrisel davranıştan doğrusal davranışa doğru yöneldiği ve $\boldsymbol{\sigma}_{\mathbf{n}}$ değerinin $3 \mathrm{MPa}$ ve daha fazla olduğu görülmektedir. $\mathrm{Bu}$ makale kapsamında yapılan çalışmalarda ise, duraysızlıkların basamak boyutunda geliştiği belirlenmiştir. Basamak yükseklikleri 10 m olduğundan, burada gelişen/gelişebilecek duraysızlıkların kayma yüzeylerinde etkin olabilecek en yüksek normal gerilmelerin $200 \mathrm{kPa}(0.2 \mathrm{MPa})$ civarında olacağ görülmektedir. Çok düşük normal gerilme değerleri kullanılarak yapılan hesaplamalar nedeniyle elde edilen grafiğin (Şekil 7) doğrusal olarak çıktığı düşünülmektedir. “ $\sigma_{\mathbf{n}}-\tau$ ” zarfinın doğrusal olması nedeniyle de duraylılık analizlerinde Mohr-Coulomb yaklaşımı kullanılmıştır.

Süreksizliklerin Schmidt sertlik değerleri ve pürüzlülükleri bozunma derecelerine de bağlı olarak farklılık gösterdiği için, hornfels birimine ait makaslama dayanım parametreleri her bir bozunma bölgesi için ayrı ayrı belirlenmiştir (Çizelge 2). 


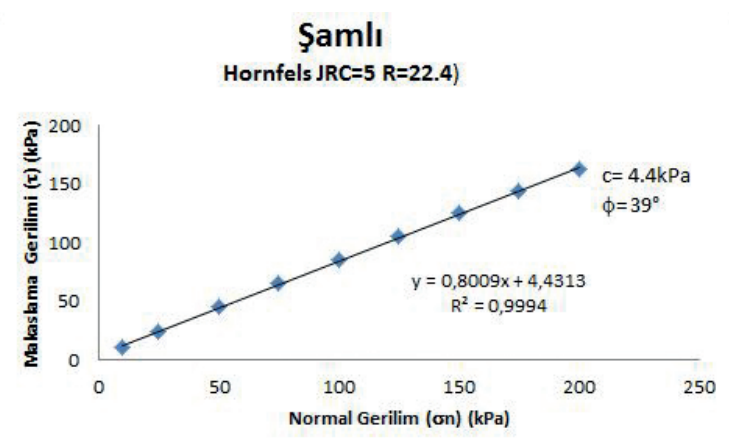

Şekil 7. Barton görgül yenilme ölçütü kullanılarak hazırlanan $\sigma_{\mathrm{n}}-\tau$ zarfina bir örnek.

Figure 7. An example for $\sigma_{n}-\tau$ envelope drawn by using Barton empirical failure criterion. batı şevlerinin kinematik ve duraylılık analizlerinde kullanılabilirliğini test etmek amacıyla bir yöntem kullanılmıştır. Güvenilirliğin araştırılmasında kullanılan bu yöntem (sınırlı sayıda da olsa yapılan araştırmalarda, bu yöntemin daha önce kullanıldığına yönelik bir literatüre rastlanılmamıştır. Yazarlar bu yöntemin elde edilen verilerin güvenilirliğini test etmede yeterli olduğunu düşünmektedirler.), kayma öncesi şev geometrisi, kaymaya neden olan süreksizliğin özellikleri ve Barton görgül yenilme ölçütünden hesaplanan genelleştirilmiş

Çizelge 2. Bozunma bölgelerine göre, farklı Schmidt sertlik (R) ve JRC değerlerine göre hesaplanan süreksizliklerin içsel sürtünme açısı ve kohezyon değerleri.

Table 2. The internal friction angle and cohesion of the discontinuities based upon weathering zone, Schmidt hummer (R) and JRC values.

\begin{tabular}{|c|c|c|c|c|c|c|c|}
\hline Birim & $\begin{array}{c}\text { Birim } \\
\text { hacim } \\
\text { ağırlık } \\
\text { (g) }\left(\mathbf{k N} / \mathbf{m}^{3}\right) \\
\text { (Ortalama) }\end{array}$ & $\begin{array}{c}\text { Bozunma } \\
\text { derecesi }\end{array}$ & $\begin{array}{c}\text { Schmidt } \\
\text { Sertlik } \\
\text { Değeri } \\
\text { (Ortalama) } \\
\text { (R) }\end{array}$ & $\begin{array}{c}\text { JCS } \\
\text { (MPa) }\end{array}$ & $\begin{array}{l}\text { Pürüzlülük } \\
\text { (JRC) }\end{array}$ & $\begin{array}{c}\text { Kohezyon (c) } \\
\text { (kPa) }\end{array}$ & $\begin{array}{l}\text { İçsel Sürtünme } \\
\text { açıs1 }(\varphi)\left({ }^{\circ}\right)\end{array}$ \\
\hline \multirow{11}{*}{ Hornfels } & \multirow{11}{*}{26.6} & \multirow{3}{*}{ W4 } & \multirow{3}{*}{22.4} & \multirow{3}{*}{34.2} & 5 & 4.5 & 39 \\
\hline & & & & & 8 & 9.6 & 45 \\
\hline & & & & & 12 & 25.2 & 53.8 \\
\hline & & \multirow{3}{*}{ W3-W4 } & \multirow{3}{*}{43.5} & \multirow{3}{*}{106.7} & 5 & 4.9 & 41.8 \\
\hline & & & & & 8 & 11.7 & 50 \\
\hline & & & & & 12 & 41.8 & 60 \\
\hline & & \multirow{3}{*}{ W3 } & \multirow{3}{*}{51.6} & \multirow{3}{*}{165.1} & 5 & 5.1 & 42.9 \\
\hline & & & & & 8 & 12.7 & 51.6 \\
\hline & & & & & 12 & 53.8 & 62.4 \\
\hline & & \multirow{2}{*}{ W3 } & \multirow{2}{*}{$54 *$} & \multirow{2}{*}{187.9} & 5 & 5.1 & 43.2 \\
\hline & & & & & 8 & 13.7 & 52.1 \\
\hline
\end{tabular}

\section{Hesaplanan Dayanım Parametrelerinin Güvenilirliğinin Değerlendirilmesi}

Barton görgül yenilme ölçütünden elde edilen genelleştirilmiş dayanım parametrelerinin, dayanım parametrelerinin girdi verisi (Çizelge 2) olarak kullanıldığ duraylılık analizidir. Burada uygulanan yöntem, duraylılık analizlerinden elde edilen güvenlik katsayılarının, limit denge 
Çağlan, Tosun, Avcı, Turunç, Kanaat

koşulu olan F = 1'e eşit/yakın olması durumunda, genelleştirilmiş parametrelerin kayma anında etkin olan dayanım parametreleri olduğuna yönelik bir kabule dayanmaktadır.

Ocak şevlerinde gelişen kayma öncesi şev geometrileri sağlıklı belirlenebilen 19 adet düzlemsel kaymada duraylılık analizleri yapılmıştır. Kayma öncesi şev geometrilerinin belirlenmesinde yaşanan en büyük zorluk, kaymaların gerçekleştiği basamakların ilksel (kayma öncesindeki) şev açılarının belirlenmesi olmuştur. Yapılan duraylılık analizlerinde her kayma için ayrı ayrı, kayma yüzeyinden alınan Schmidt sertlik ve JRC değerleri dikkate alınarak geliştiği bölgenin bozunma derecesine göre hesaplanan genelleştirilmiş dayanım parametreleri (Çizelge 2) kullanılarak güvenlik katsayıları hesaplanmıştır.

Duraylı1ık analizleri sonucunda, düzlemsel kaymalar için elde edilen güvenlik katsayılarının 0.90 - 1.05 arasında değiştiği, ortalama değerin
0.99 olduğu saptanmıştır. Ortalama değer dikkate alındığında, bu değerin, limit denge koşuluna göre kayma anında geçerli olduğu kabul edilen $\mathrm{F}=1$ güvenlik katsayısına çok yakın olduğu görülmektedir. $\mathrm{Bu}$ nedenle duraylılık analizlerinde Barton görgül yenilme ölçütünden hesaplanan genelleştirilmiş dayanım parametrelerinin kullanılmasının uygun olduğuna karar verilmiştir. Yapılan analize örnek olarak, basamak boyutunda etkili olan, Doğu Ocak güney şevlerinde W4-W5 bozunma zonunda, 45 nolu ölçüm noktasında (Şekil 3) saptanan düzlemsel kaymanın duraylılık analizi Şekil 8'de verilmiştir. Bu örnekte, 45 nolu ölçüm noktasındaki düzlemsel kaymanın kayma yüzeyinde saptanan pürüzlülülük katsayısı ve Schmidt sertlik değerlerine $(\mathrm{JRC}=6-8, \mathrm{R}=29)$ en yakın olan ortalama değerler $(\mathrm{JRC}=8, \mathrm{R}=$ 22.4) kullanılarak hesaplanan genelleştirilmiş dayanım parametreleri esas alınmıştır (Bkz. Çizelge 2).

Çizelge 3. Duraylılık analizlerinde kullanılan parametreler ve hesaplanan güvenlik katsayıları.

Table 3. The parameters used in the stability analyses and calculated factor of safeties.

\begin{tabular}{|c|c|c|c|c|c|c|}
\hline \multirow[b]{2}{*}{ Duraysızlık türü } & \multirow{2}{*}{$\begin{array}{l}\text { Bozunma } \\
\text { Derecesi }\end{array}$} & \multirow[b]{2}{*}{ Pürüzlülük katsayısı (JRC) } & \multicolumn{2}{|c|}{ Şev } & \multicolumn{2}{|c|}{$\begin{array}{c}\text { Güvenlik katsayısı } \\
\text { (F) }\end{array}$} \\
\hline & & & $\begin{array}{l}\text { Yüksekliği } \\
\text { (H) (m) }\end{array}$ & $\begin{array}{l}\text { Şev } \\
\text { Aç1S1 } \\
\left({ }^{\circ}\right)\end{array}$ & $\begin{array}{l}\text { Statik } \\
(\mathrm{F})\end{array}$ & $\begin{array}{l}\text { Depremli } \\
\qquad\left(\mathrm{F}_{\mathrm{d}}\right)\end{array}$ \\
\hline \multirow{2}{*}{ Düzlemsel } & \multirow{2}{*}{ W3-W4 } & 8 & \multirow{6}{*}{10} & 65 & 1.39 & 1.00 \\
\hline & & 5 & & 50 & 1.31 & 0.92 \\
\hline \multirow{2}{*}{$\begin{array}{l}\text { Kama (kuzey kanat } \\
\text { şevleri) }\end{array}$} & \multirow{4}{*}{ W3-W4 } & 5 (Her iki kayma yüzeyi) & & \multirow{4}{*}{65} & 1.19 & 0.84 \\
\hline & & Bir yüzey 5 , diğer yüzey 8 & & & 1.32 & 0.93 \\
\hline \multirow{2}{*}{$\begin{array}{c}\text { Kama (güney kanat } \\
\text { şevleri) }\end{array}$} & & 5 (Her iki kayma yüzeyi) & & & 1.18 & 0.83 \\
\hline & & $\begin{array}{l}\text { Bir yüzey } 5 \text {, } \\
\text { diğer yüzey } 8\end{array}$ & & & 1.54 & 1.12 \\
\hline
\end{tabular}


Factor of Safety. 1.02897

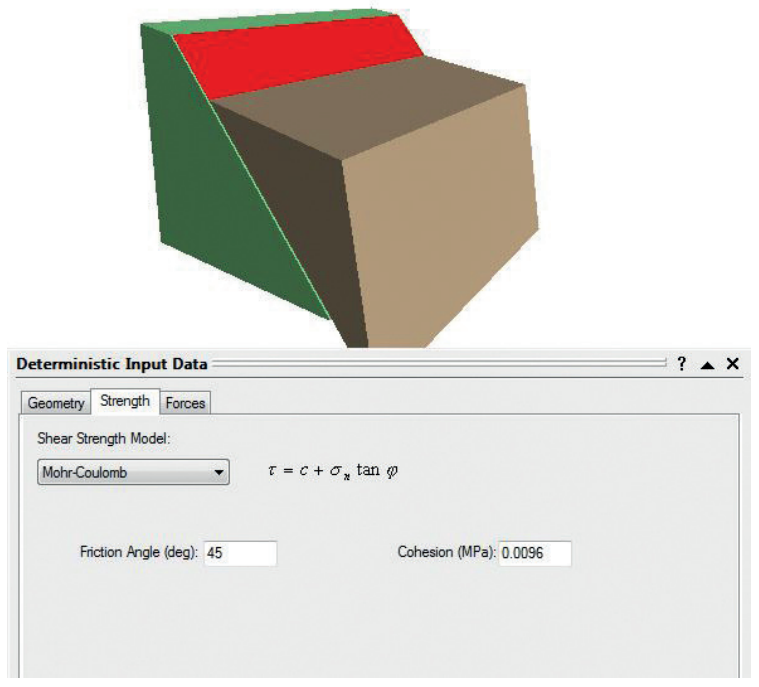

Şekil 8. Genelleştirilmiş dayanım parametreleri kullanılarak yapılan 45 nolu ölçüm noktasında saptanan düzlemsel kaymanın kuru koşullardaki duraylılık analizi $\left(\mathrm{H}=10 \mathrm{~m}, \alpha=80^{\circ}\right)$.

Figure 8. The stability analysis of location 45 performed by using shear strength parameters obtained from dry discontinuity surfaces.

\section{Duraylılık İncelemeleri}

Doğu Ocağı'nın batı kesiminde oluşturulması planlanan şevler, batı şevleri kuzey kanat ve batı şevleri güney kanat olarak iki ana bölgeye ayrılarak incelenmiştir.

Ocağın batıkesimindeoluşturulacakşevlerde genelde W3 (orta derecede bozunmuş) ve W3W4 (orta-çok bozunmuş) kaya kütleleri yayılım göstermektedir. Arazi çalışmaları sırasında Doğu Ocağı'nın batı şevlerinde kaymalara neden olabilecek süreksizlik yüzeylerine ait pürüzlülük değerlerinin genelde JRC $=8$ civarında olduğu belirlenmiştir. Şevlerin eğim açıları ve eğim yönlerinin belirlenmesinde proje mühendisleri tarafından hazırlanan planlar kullanılmıştır (Şekil 3). Bu planlarda batı şevlerinin kuzey kanadının eğim yönü $218^{\circ}$, güney kanadının eğim yönü $34^{\circ}$, basamak yükseklikleri $(\mathrm{H}) 10 \mathrm{~m}$, basamak şev açıları $(\alpha) 70^{\circ}$ olarak kabul edilmiştir.

Süreksizliklerin ondülasyonları, (Golder Assocates, 1979)'e göre yapilan siniflandirma dikkate alınarak az dalgalı olarak belirlenmiştir. Arazide kayma yüzeyleri üzerinde yapılan incelemelerde de dalgalılık gözlenmemiştir. Doğu Ocak batı şevlerinin oluşturulacağ 1 kesim, büyük ölçüde örtülü olup, kaya birimler gözlenememektedir. Duraylilık analizlerinde, bu durum göz önüne alınarak, güvenli tarafta kalınabilmesi amacıyla dalgalılık açısı $0^{\circ}$ olarak kabul edilmiştir.

\section{Kinematik analizler}

İlk olarak Hoek ve Bray (1981) tarafindan tanımlanmışkinematikanalizyöntemi, düzlemsel, kama tipi ve devrilme türü duraysızlıkların araştırılmasında kullanılmaktadır. Bu yöntem, kayma düzleminin, makaslama dayanım parametrelerinden sadece içsel sürtünme açısını ( $\varphi)$ dikkate almaktadır. Yöntemin esası, şev düzlemi, kayma ve/veya devrilme potansiyeline sahip süreksizlik düzlemi ve yüzey sürtünme açısının birbirleriyle karşılaştırılmasına dayanmaktadır. $\mathrm{Bu}$ çalışmada, kinematik analizlerde Schmidt eş alan neti kullanılmıştır.

Yeni oluşturulacak batı şevlerinin büyük bir kısmı örtülüdür. $\mathrm{Bu}$ nedenle bu şevleri temsil edecek yeterli sayıda süreksizlik ölçümü yapılamamıştır. Ocağın kuzey ve güney şevleri ile mevcut batı şevlerinden alınan süreksizlik ölçülerinin ayrı ayrı değerlendirilmesi sonucunda, süreksizlik yönelimlerinin pek fazla değişmediği belirlenmiştir (Şekil 9). Bu nedenle oluşturulacak batı şevlerininin kinematik analizlerinde, 
Çağlan, Tosun, Avcı, Turunç, Kanaat

ocağın tamamından alınan süreksizlik verileri kullanılmıştır. Süreksizliklerin gül diyagramı çizildiğinde, iki adet ana iki adet de tali süreksizlik yönelimi saptanmıştır (Şekil 10). Ancak bu süreksizlik sistemlerinin kutup noktalarının stereonet üzerindeki dağılımlarına bakıldığında, noktaların belli bölge ve/veya bölgelerde toplanmayıp bütün ă̆ üzerinde dağılım gösterdiği görülmektedir (Şekil 11). Diğer bir anlatımla, kutup yoğunlaşma noktaları belirgin olarak gözlenememektedir.
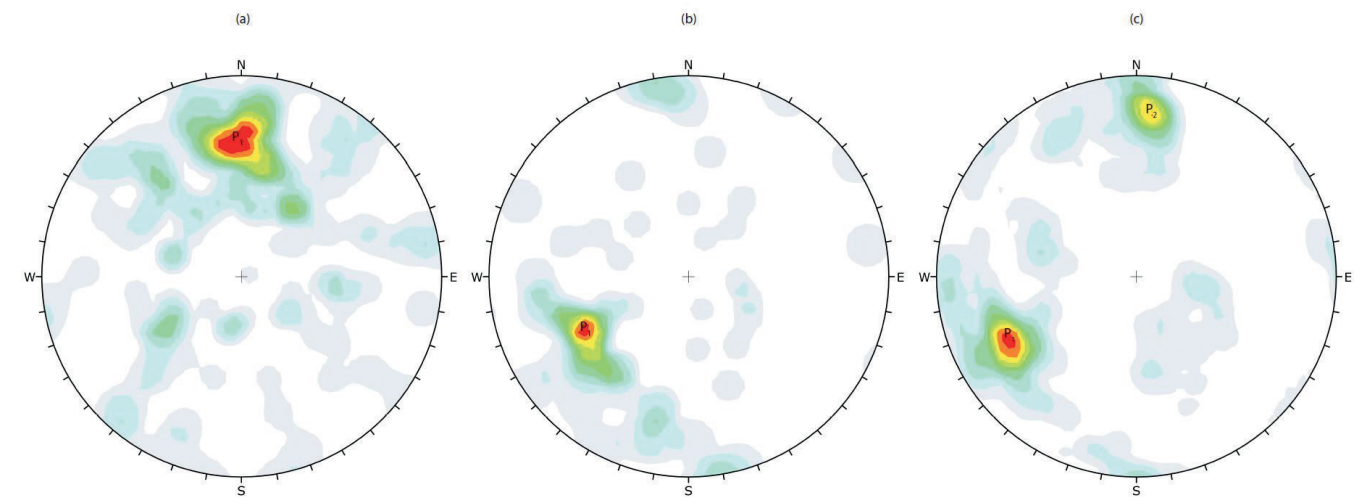

Şekil 9. Doğu Ocak şevlerinden alınan süreksizlik ölçümleri, a) kuzey şevleri, b) güney şevleri, c) batı şevleri.

Figure 9. Discontinuity measurements from the Doğu Ocak of (a) northern slopes b) southern slopes c) western slopes.

(a)

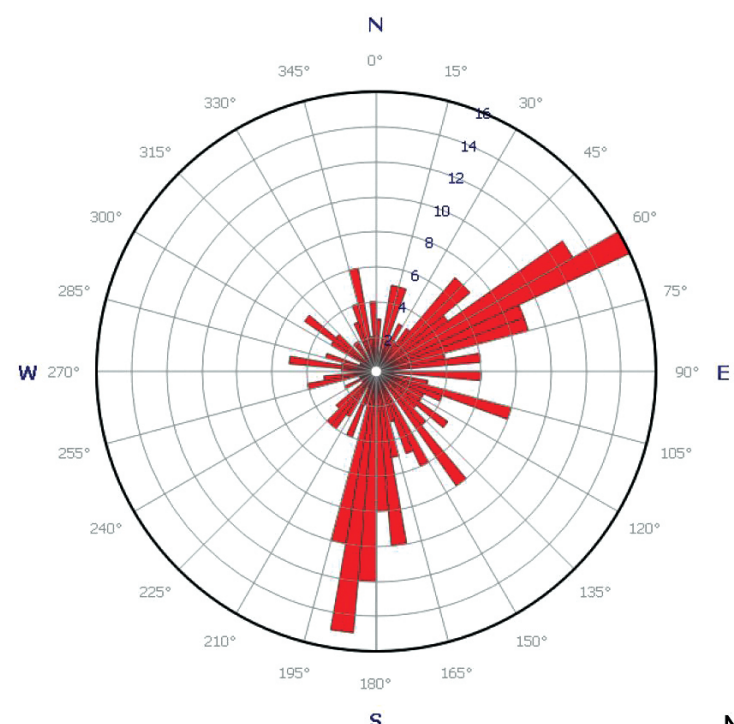

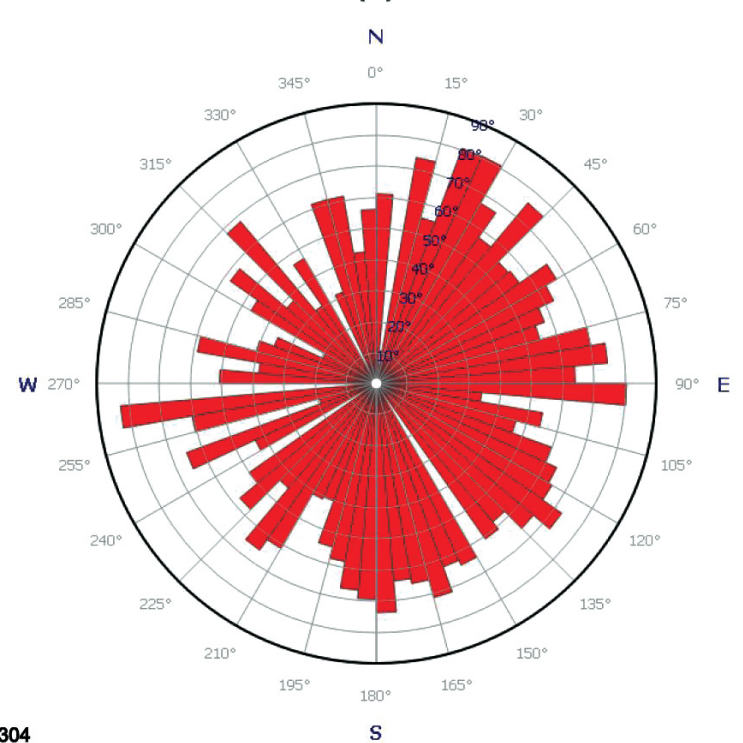

$N=304$ (b)

Şekil 10. Şamlı Doğu ocağından alınan süreksizlik ölçümlerinin (a) eğim yönlerine ve (b) eğim açılarına göre gül diyagramı.

Figure 10. The rose diagram of the discontinuity measurements at Şamlı Doğu ocak based upon a) dip direction and b) dip amount. 
(a)

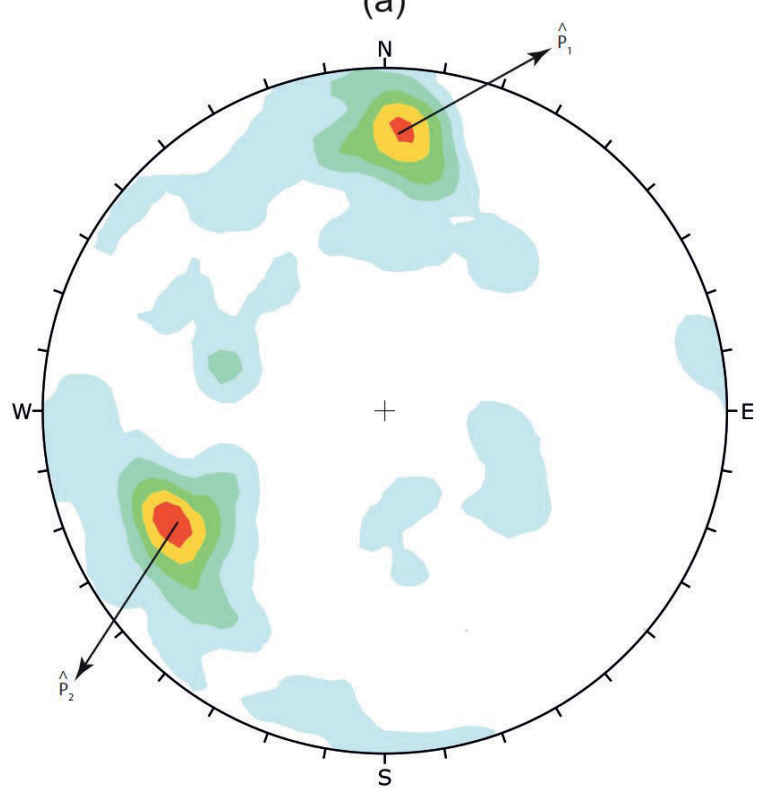

(b)

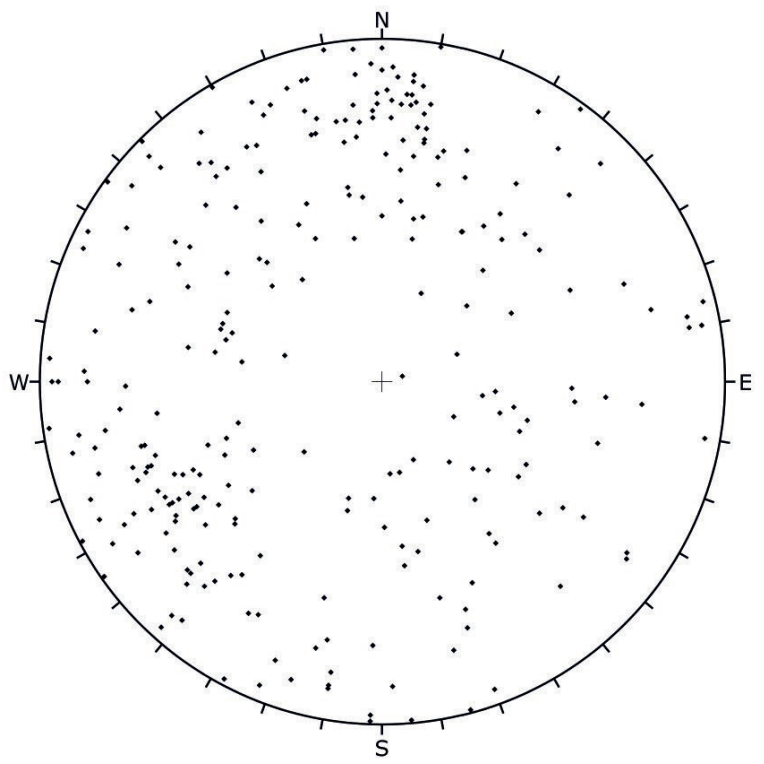

Şekil 11. Süreksizliklerin kontur diyagramı ve kutup noktalarının stereonet üzerindeki dağılımları.

Figure 11. The contour diagram of the discontinuities surfaces and the distribution of their poles on stereonet.

Kinematik anlamda, Doğu Ocağı'nın kuzey ve güney şevlerinde saptanan tüm süreksizliklerin (Şekil 12a) ve kaymalara neden olan süreksizliklerin (Şekil $12 \mathrm{~b}$ ve c). stereonet üzerindeki dağılımları incelenmiştir. $\mathrm{Bu}$ süreksizliklere bağlı gelişmiş duraysızlıkların oluşumlarında, kuzey şevlerinde genelde yaklaşık doğu-batı uzanımlı ve güneye eğimli süreksizlikler etkin olurken, güney şevlerinde ise, doğrultuları kuzeybat1-güneydoğu, eğimleri kuzeydoğu olan süreksizliklerin etkin olduğu görülmüştür. Genel olarak, Şekil 12'de kutup noktalarının en yoğun olduğu kırmızı renkli konturların temsil ettiği süreksizliklerin, arazide saptanan düzlemsel kaymalara neden olan süreksizliklere, geniş bir alana yayılım sunan mavi renkli konturların ise kama tipi kaymalara neden olan süreksizliklere karşılık geldiği belirlenmiştir. 

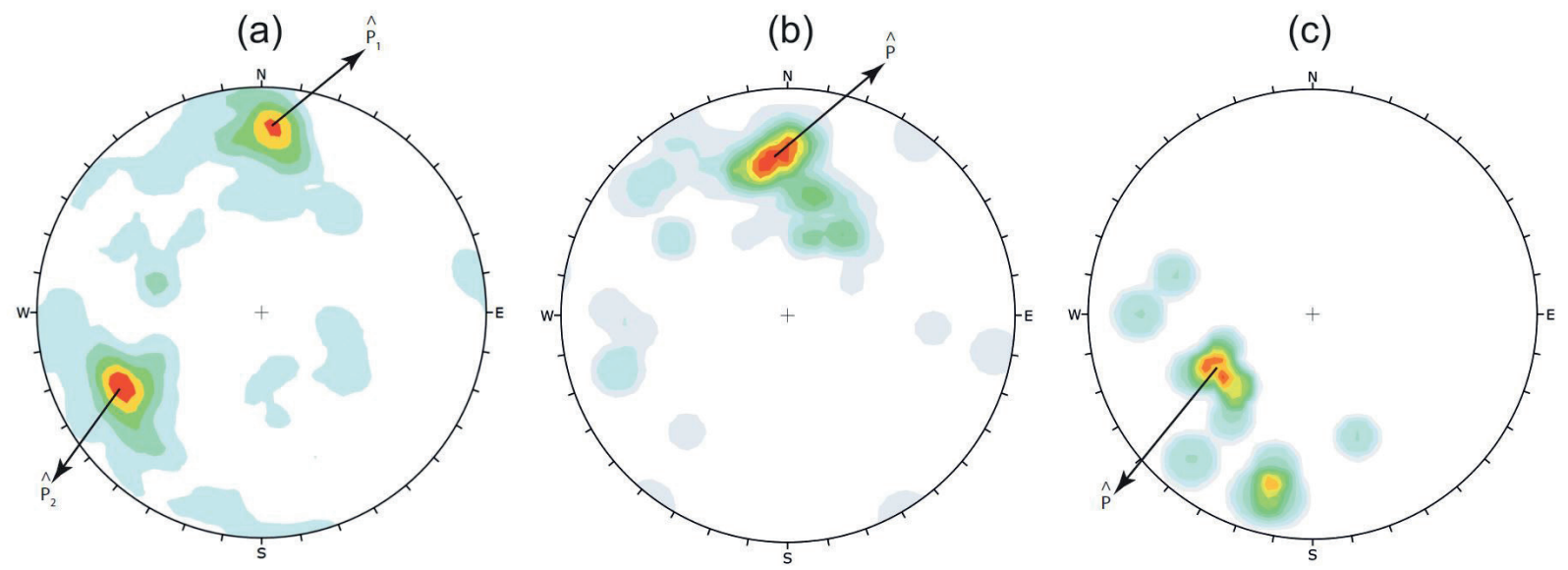

Şekil 12. Duraysızlıklara neden olan süreksizliklerin stereonet üzerindeki dağılımı: a) Ocağın tamamına ait süreksizlikler, b) Kuzey şevleri, c) Güney şevleri

Figure 12. Distribution of the discontinuities causing instabilities for (a) whole pit, (b) northern slope, (c) southern slope.

Yeni oluşturulacak batı şevlerinin kuzey ve güney kanatlarının yönelimleri, Doğu Ocağı'nın kuzey ve güney şevleriyle yaklaşık uyumlu oluğundan (Şekil 3), gelişebilecek duraysızlıklarda da aynı süreksizlik setlerinin etkin olacağı düşünülmektedir. Batı şevleri kuzey kanat için yapılan kinematik analizler sonucunda, $70^{\circ}$ olarak planlanan basamak şev açısının $65^{\circ}$ ye düşürülmesi koşulunda da, mevcut şev geometrisinde düzlemsel, kama ve devrilme türü duraysızlıkların gelişebileceği görülmektedir (Şekil 13).
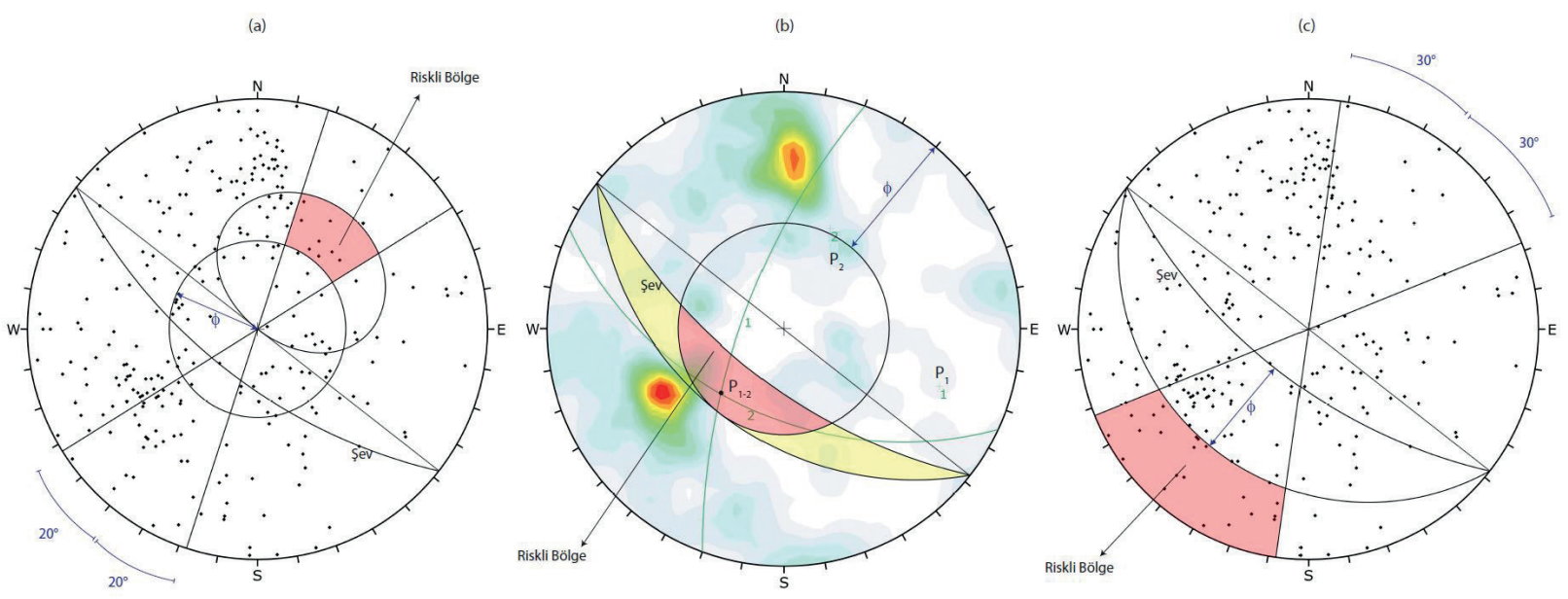

Şekil 13. Doğu ocak batı şevleri kuzey kanadının kinematik analizleri sonuçları: a) düzlemsel kaymalar, b) kama tipi kayma, c) devrilme.

Figure 13. Kinematic analysis of western side of the northern slopes at Doğu ocak: a) planar sliding, b) wedge sliding, c) toppling. 
Olası düzlemsel kaymaların büyük bir bölümünün önlenebilmesi için şevlerinin eğim yönlerinin $252^{\circ}$ olarak planlanmas1 gerekmektedir. Ancak, bu durum Doğu ve Batı Ocakları'nın birleştirilmesi planı ileçelişmektedir (Şekil 14). Bu nedenle, yapılan çalışmalar, olası duraysızlıkları önlemek için şev doğrultuları yerine eğim açılarının değiştirilmesi üzerine yoğunlaştırılmıştır. Ancak bu durumda, şev açısı $50^{\circ}$ 'ye düşürülse bile, düzlemsel kaymaları tamamen önlemek mümkün olamamaktadır (Şekil 15).

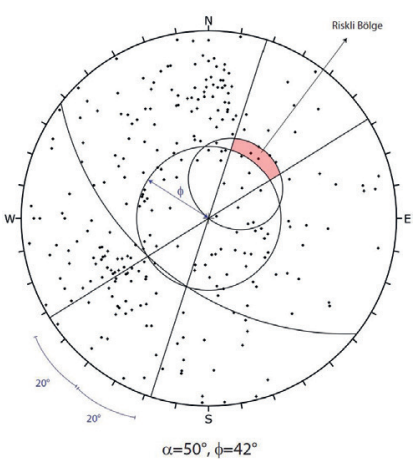

Şekil 15. Batı şevleri kuzey kanat basamak şev açısı $(\alpha)$ $50^{\circ}$ olması koşulunda düzlemsel kaymaların kinematik analizi.

Figure 15. The kinematic analysis of planar sliding in the case that northern side of western slope $(\alpha)$ is $50^{\circ}$.

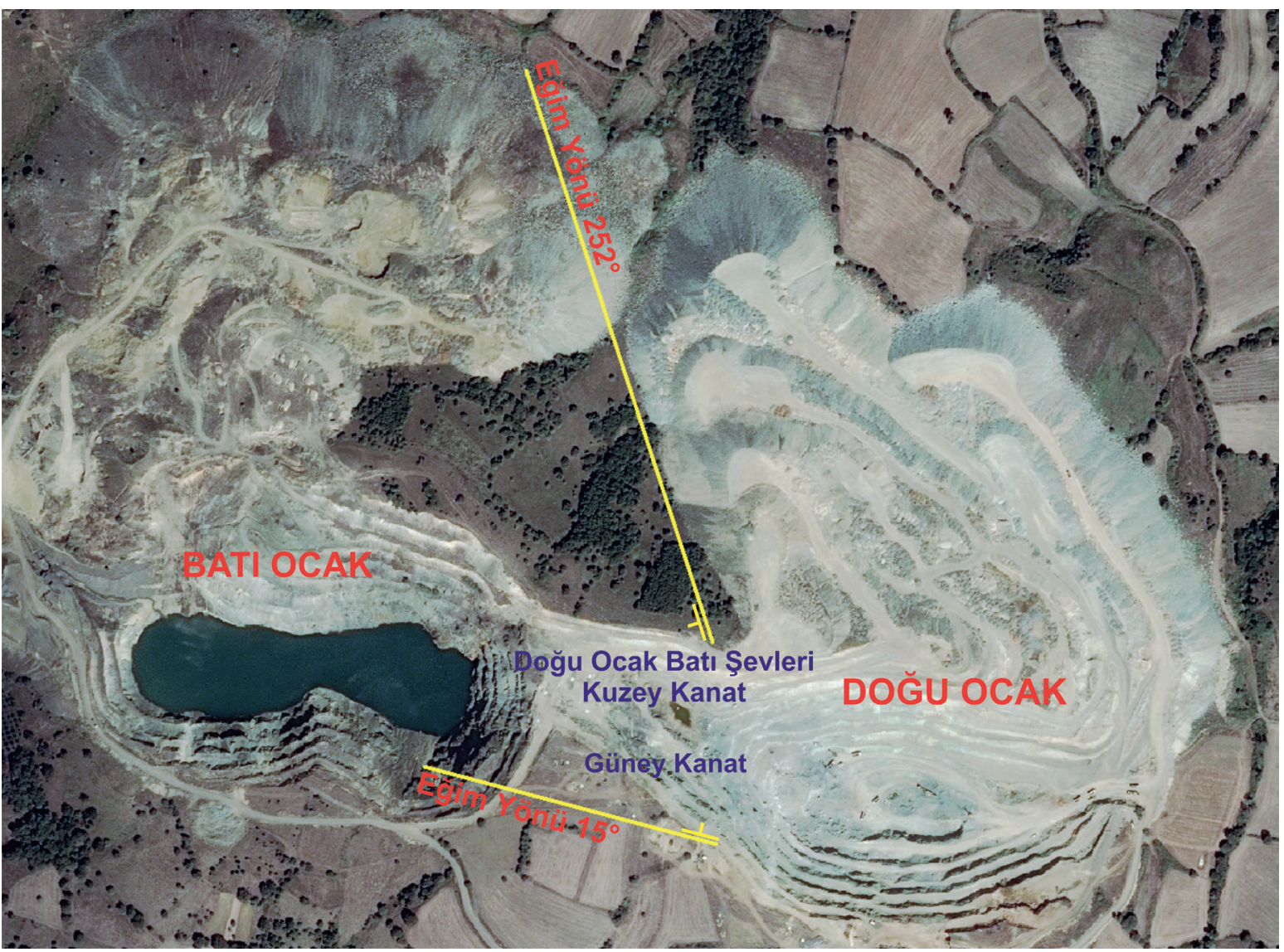

Şekil 14. Batı şevleri Kuzey kanat eğim yönünün $252^{\circ}$ olması durumunda Doğu ve Batı ocaklarının birleșememe durumu.

Figure 14. The eastern and northern slopes cannot be met in case dip direction of the northern side of the western slope is $252^{\circ}$ when Doğu Ocak and Batı Ocak are merged. 
Çağlan, Tosun, Avcı, Turunç, Kanaat

Batı şevleri güney kanat için planlanan şev doğrultuları (eğim yönü $34^{\circ}$ ) esas alınarak yapılan kinematik analizler sonucunda da basamak şev açısının $65^{\circ}$ olması koşulunda düzlemsel, kama ve devrilme türü duraysızlıkların gelişebileceği görülmektedir (Şekil 16).

Güney kanat şev eğim yönlerinin başlangıçta planlanan $\quad 34^{\circ}$ den $15^{\circ}$ ye değiştirilmesi durumunda, riskli bölgeye, düzlemsel kaymaya neden olabilecek yalnızca bir adet süreksizlik düzlemine ait kutup noktası düşmektedir (Şekil 17). $\mathrm{Bu}$ koşulun bölgedeki olası düzlemsel kaymaları çok büyük bir oranda azaltacağ1 açıktır. Ayrıca, şevlerin eğim yönlerinin $15^{\circ}$ olarak planlanması iki ocağın birleşmesinde herhangi bir sorun oluşturmamaktadır (Şekil 14).
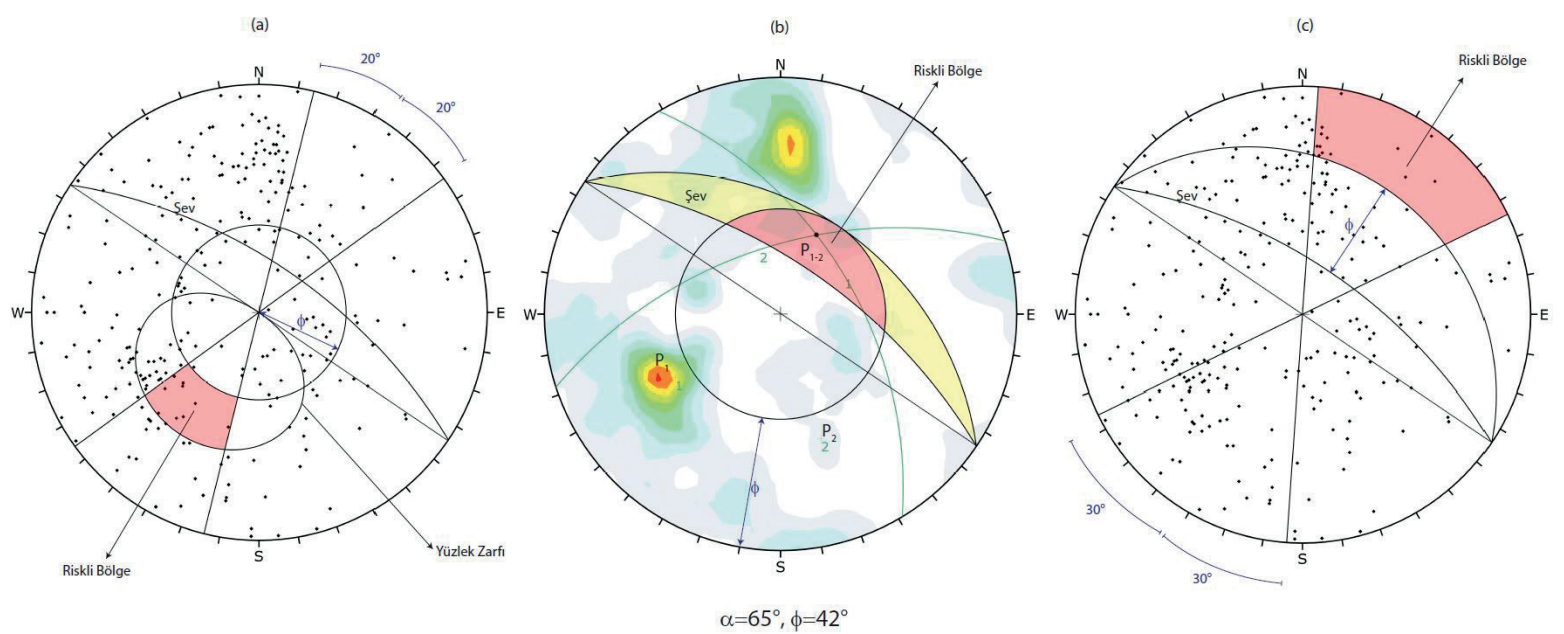

Şekil 16. Batı şevleri güney kanadının kinematik analiz sonuçları: a) düzlemsel kaymalar, b) kama tipi kayma, c) devrilme.

Figure 16. Results of kinematic analyses for a) planar sliding, b) wedge sliding, c) toppling at southern side of the western slope.

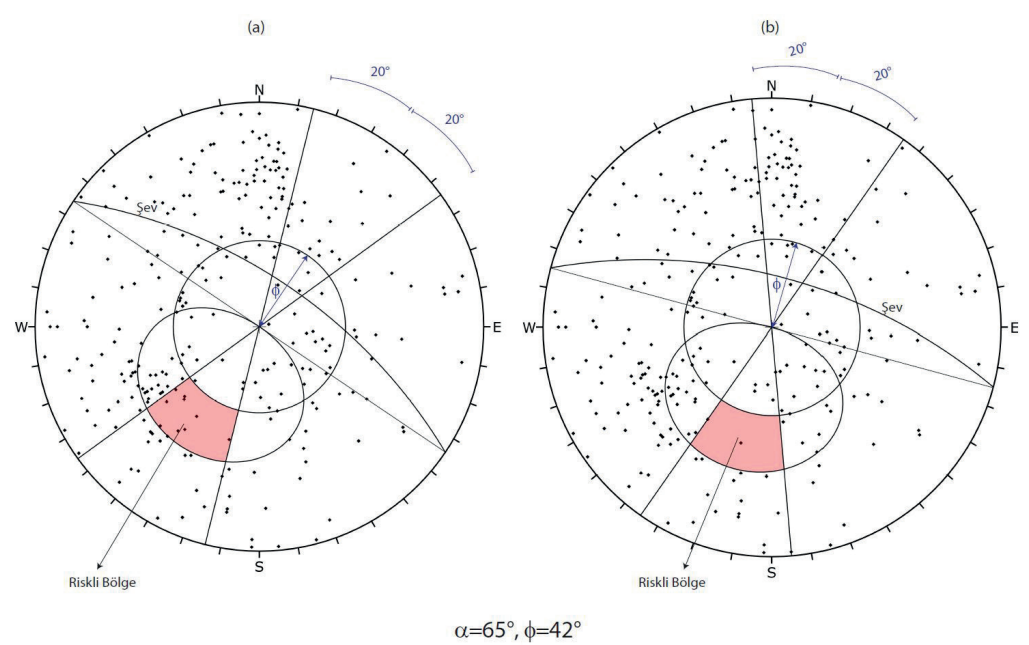

Şekil 17. Batı şevleri güney kanadının a) eğim yönü $34^{\circ}$, b) eğim yönü $15^{\circ}$ için düzlemsel duraysılıkların kinematik analizleri. Figure 17. Kinematic analyses of planar sliding based upon a) $34^{\circ}$ and b) $15^{\circ}$ dip directions at southern side of the western slope. 
Güney kanat kama tipi kayma potansiyeli için yapılan kinematik analizlerde kayma potansiyeli oluşturan süreksizliklerin kesişme noktaları, şevlerin eğim yönlerinin hem $34^{\circ}$ hem de $15^{\circ}$ olması koşulunda, kritik bölge içerisinde kalmaktadır (Şekil 18). Şekil 18'de kama tipi duraysızlığa neden olabilecek (duraylılık analizlerinde en düşük güvenlik katsayısını veren) süreksizliklerin kesişme noktası örnek olarak gösterilmiştir.
Batı şevlerinin kuzey ve güney kanatlarında, kinematik olarak devrilme potansiyeli vardır. Güney kanat için eğim yönleri $34^{\circ}$ ve $15^{\circ}$ olan şevler için devrilme potansiyeli de kinematik olarak incelenmiş ve devrilme türü duraysızlığın gelişebileceği belirlenmiştir (Şekil 19). Ancak, şevin eğim yönünün $15^{\circ}$ olması durumunda devrilme açısından riskli bölgeye düşen süreksizlik sayısının arttığı görülmektedir.

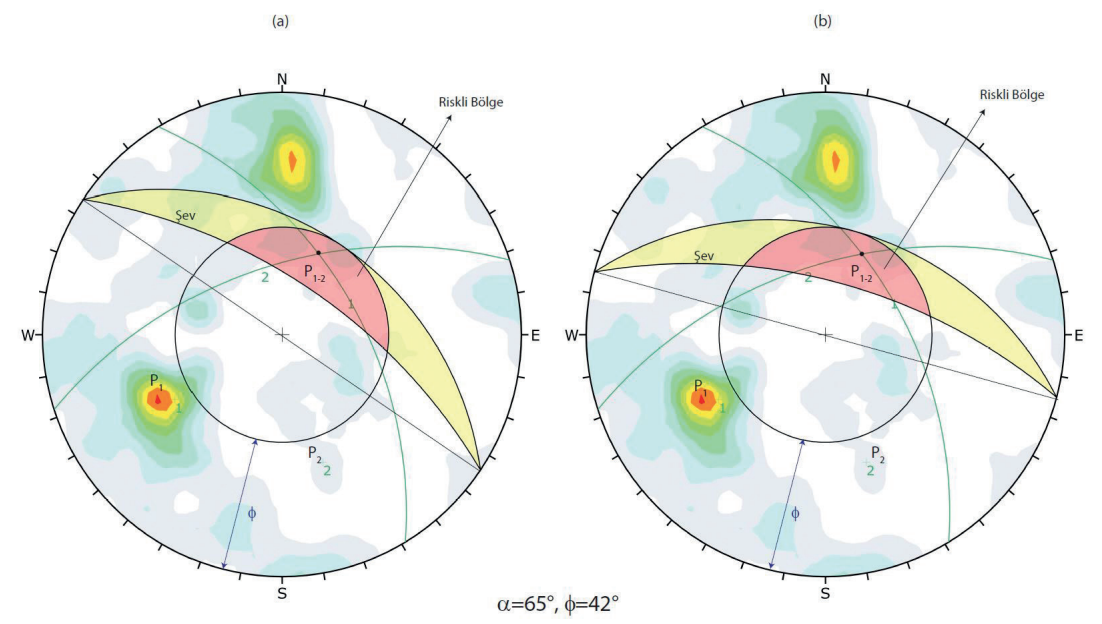

Şekil 18. Batı şevlerinin güney kanadının a) eğim yönü $34^{\circ}$, b) eğim yönü $15^{\circ}$ için kama tipi duraysızlıkların kinematik analizleri. Figure 18. Kinematic analyses of wedge sliding based upon a) $34^{\circ}$ and b) $15^{\circ}$ dip directions at southern side of the western slope.

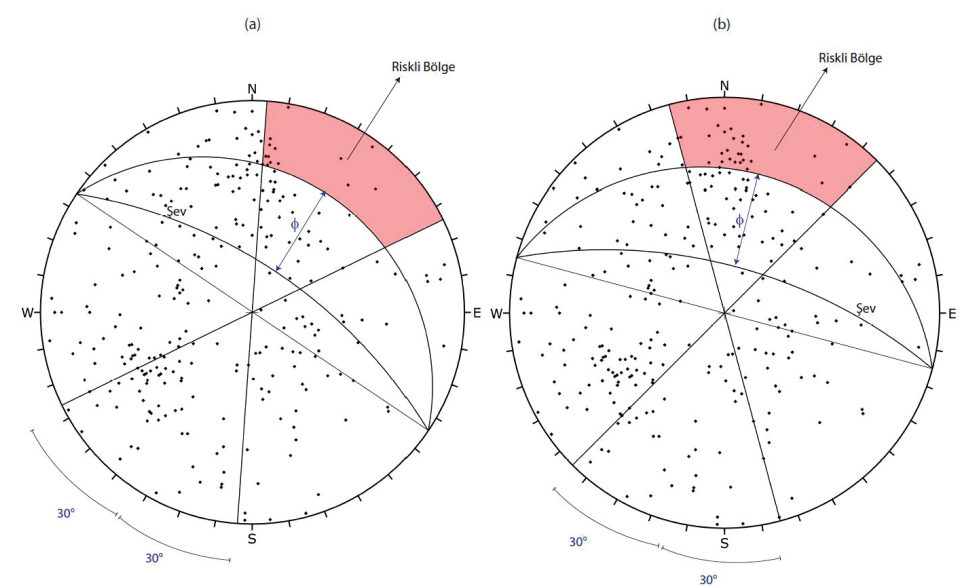

Şekil 19. Batı şevlerinin güney kanadının a) eğim yönü $34^{\circ}$, b) eğim yönü $15^{\circ}$ için devrilme tipi duraysızlıkların kinematik analizleri.

Figure 19. Kinematic analyses of toppling based upon a) $34^{\circ}$ and b) $15^{\circ}$ dip directions at southern side of the western slope. 
Çağlan, Tosun, Avcı, Turunç, Kanaat

Arazi çalışmaları sırasında, Doğu ocağının kuzey ve güney şevlerinin eğim yönlerinin batı şevleri kuzey kanat ve güney kanat şev eğim yönleriyle uyumlu olan kesimlerinde devrilme türü duraysızlık gözlenmemiştir. $\mathrm{Bu}$ nedenle kinematik olarak devrilme potansiyeli bulunmasına karşın, batı şevleri kuzey kanadında devrilme türü duraysızlık beklenmemektedir.

\section{Duraylılık analizleri}

Duraylılık analizleri limit denge kavramını esas alan iki boyutlu deterministik analiz yöntemleri ile yapılmıştır.

Düzlemsel kaymalar için yapılan duraylılık analizlerinde kullanılan programlarda, şevlerin yönelimleriyle ilgili parametre değerlendirilmeye alınmamaktadır. Bu nedenle, batı şevleri kuzey kanat ve güney kanat için ayrı ayrı düzlemsel kayma duraysızlık analizleri yapılmamıştır. Yapılan kinematik analizler dikkate alınarak duraylılık analizlerinde şev eğimlerinin öncelikle $65^{\circ}$ olması koşulu araştırılmıştır. Duraylılık analizlerinde basamak yükseklikleri (H) $10 \mathrm{~m}$ ve şevler kuru olarak kabul edilmiştir.

Duraylıl1k analizleri dinamik (depremli) koşullar için de gerçekleştirilmiştir. Çalışma alanımıza en yakın aktif fay Şamlı Fayı'dır ve $\mathrm{Mw} \geq 6.0$ büyüklüğünde deprem üretme potansiyelinin olmasi nedeniyle analizlerde yatay ivme $0.2 \mathrm{~g}$ olarak alınmıştır.

Yapılan duraylılık analizlerinin sonuçları Çizelge 3'te verilmiştir.
Düzlemsel kayma duraylılık analizleri sonucunda, süreksizlik yüzeylerine ait pürüzlülük katsayılarının JRC $=8$ olması durumunda W3W4 ve W3 bozunma dereceli zonlar için elde edilen dayanım parametreleriyle hesaplanan güvenlik katsayılarının 1.3'ten büyük ( $\mathrm{F}>1.3$ ) olduğu belirlenmiştir (Şekil 20a, Çizelge 3). Bu katsayılar, açık ocak şevlerinde statik koşullar için kabul edilen güvenlik katsayılarıyla uyumludur. W3-W4 dereceli bozunma zonunda, pürüzlülük katsayısının JRC $=5$ olması durumunda ise basamak şev açılarının $50^{\circ}$ 'ye kadar düşürülmesi koşulunda $\mathrm{F}>1.3$ değeri elde edilebilmektedir (Şekil 20a, Çizelge 3). Depremli koşul için yapılan analizlerde ise güvenlik katsayıları W3-W4 bozunma zonunda JRC $=8$ olmas1 durumunda $\mathrm{F}_{\mathrm{d}}=1.0, \mathrm{JRC}=5$ olmas1 durumunda $\mathrm{F}_{\mathrm{d}}<1.0$ elde edilmektedir ( Şekil 21, Çizelge 3). (a)

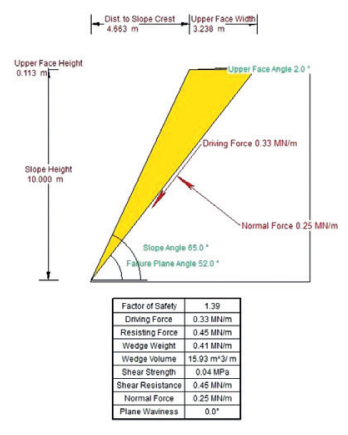

(b)

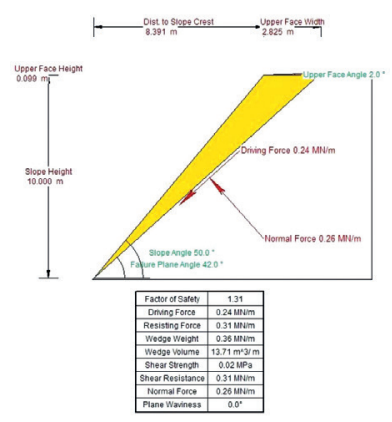

Şekil 20. Düzlemsel kaymaların W3-W4 bozunma zonunda statik koşulda $\mathrm{F} \geq 1.3$ sağlayan durayl11ık analizleri a) $\mathrm{JRC}=8 \mathrm{~b}$ ) $\mathrm{JRC}=5$ için.

Figure 20. In W3-W4 weathering zones, the stability analysis of planar sliding in the case of $F \geq 1.3$ for a) $J R C=8$ and b) $J R C=5$ under static conditions. 
(a)

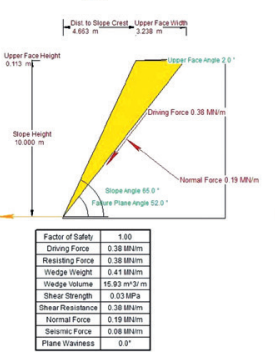

(b)

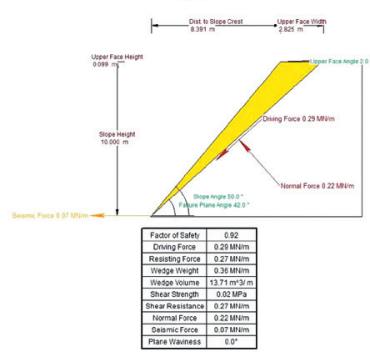

Şekil 21. Düzlemsel kaymaların W3-W4 bozunma zonunda depremli koşul için duraylılık analizleri a) $\mathrm{JRC}=8 \mathrm{~b}$ ) $\mathrm{JRC}=5$ için.

Figure 21. In W3-W4 weathering zone, the stability analysis of planar sliding under dynamic conditions induced by earthquake and for a) $J R C=8$ and $b$ ) $J R C=5$ values.

Kuzey kanat kama tipi kaymaların duraylılık analizlerinde, kayma potansiyeline

(a)

Factor of Safery. 1.1944

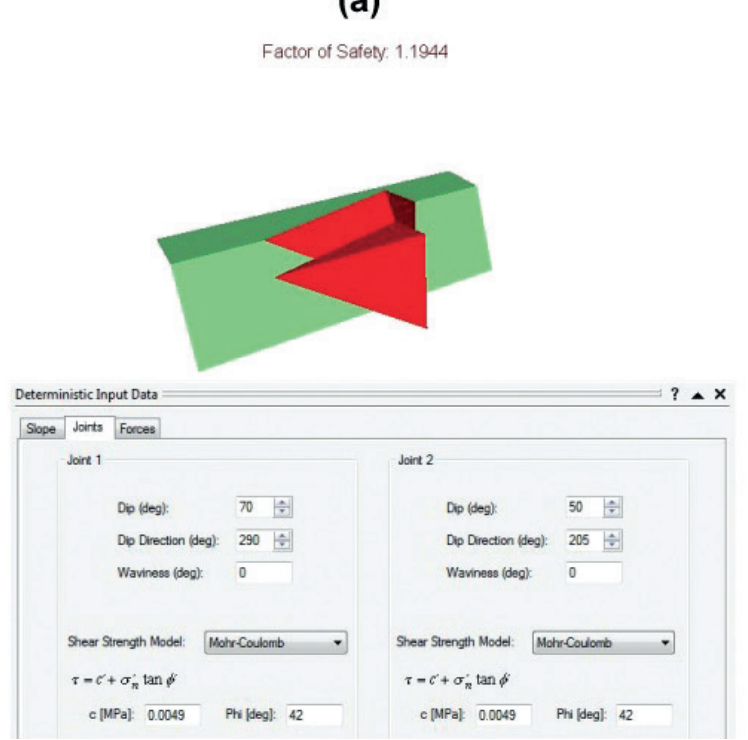

sahip süreksizliklere (Şekil 13b) ait eğim açısı/ eğim yönü değerleri kullanılmıştır. Kama tipi duraysızlığı oluşturan süreksizliklerin dayanım parametreleri olarak JRC $=5$ için hesaplanan dayanım parametreleri kullanıldığında, elde edilen en düşük güvenlik katsayısı statik koşulda $\mathrm{F}=1.19^{\prime}$ 'dur (Şekil 22a, Çizelge 3). Ancak, kamanın herhangi bir kanadı için JRC $=5$ yerine $\mathrm{JRC}=8$ için hesaplanan dayanım parametreleri kullanıldığında ise güvenlik katsayısının 1.3'ün üzerinde kaldığı görülmektedir (Şekil 22b, Çizelge 3). Depremli koşullar altında kamanın her iki kanadının pürüzlülük değeri JRC $=5$ olduğunda $\mathrm{F}_{\mathrm{d}}=0.84$ (Şekil 23a, Çizelge 3), herhangi bir kanat için pürüzlülük değeri JRC $=8$ alındığında ise $\mathrm{F}_{\mathrm{d}}=0.93$ değeri elde edilmektedir (Şekil 23b, Çizelge 3).

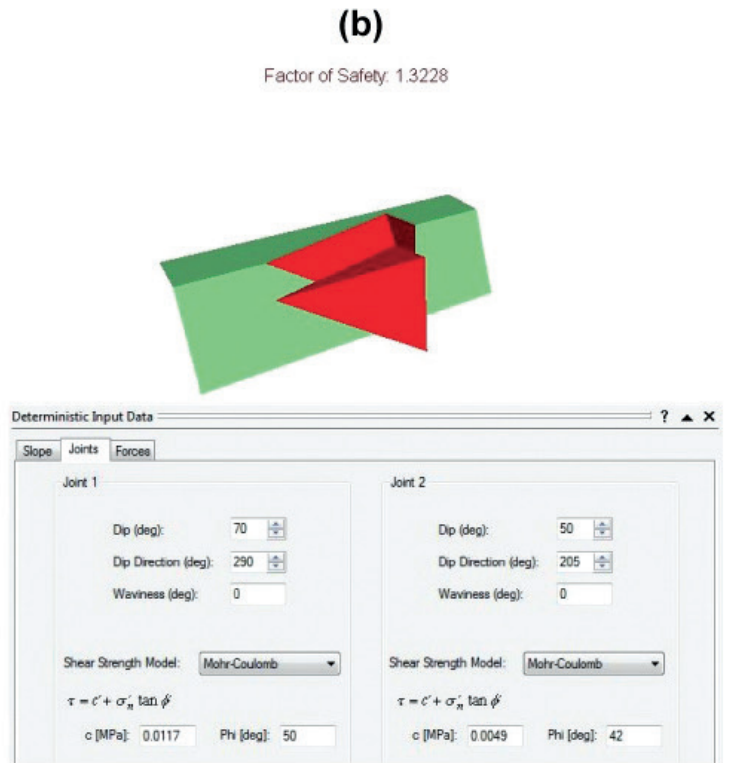

Şekil 22. Kuzey kanat şevlerinin kama tipi kaymalarda a) her iki yüzey JRC $=5$ için, b) yüzeylerden biri JRC $=5$ diğeri ise JRC $=8$ için statik koşullarda duraylılık analizi.

Figure 22. Stability analysis of wedge sliding at northern side of the western slope based upon a) JRC=5 for both faces, and b) $J R C=5$ for one face and $J R C=8$ for other face under static conditions. 
Çağlan, Tosun, Avcı, Turunç, Kanaat

(a)

Factor of Safety. 0.8374

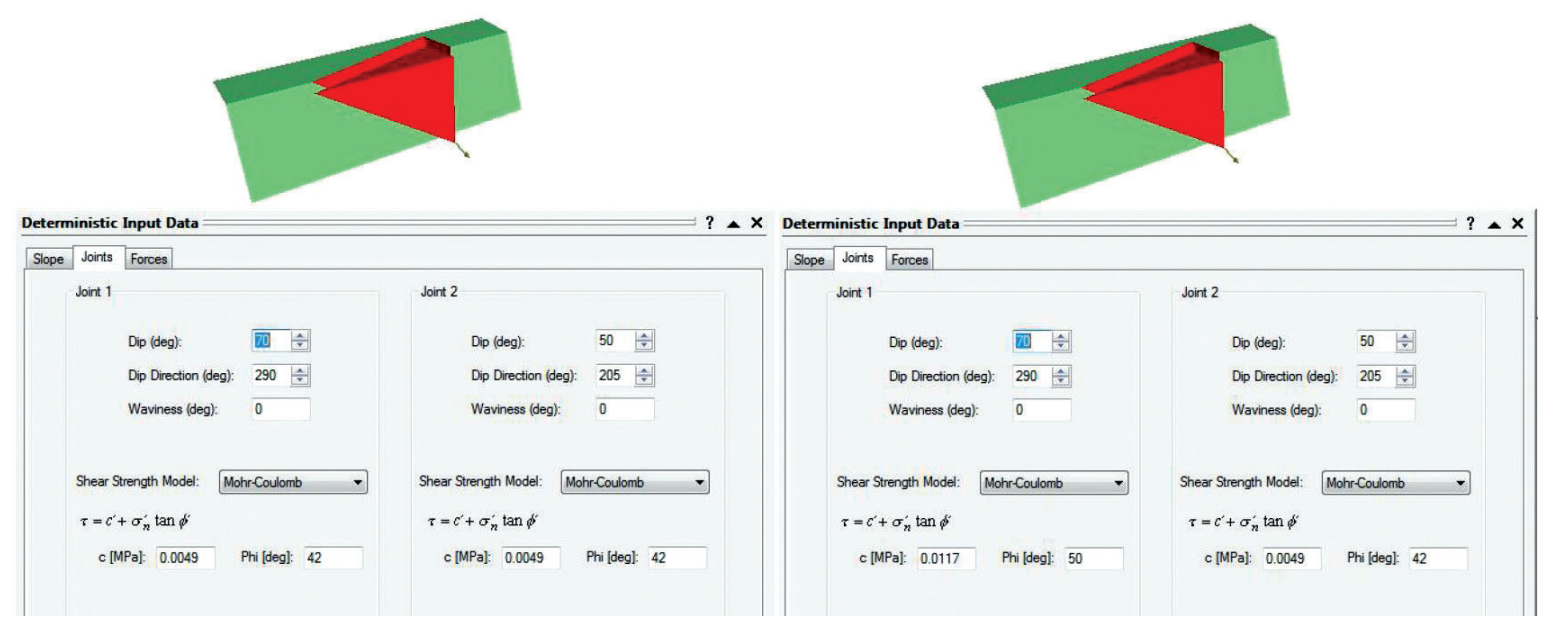

(b)

Factor of Safety: 0.9335

Şekil 23. Kuzey kanat şevlerinin kama tipi kaymalarda a) her iki yüzey JRC $=5$ için, b) yüzeylerden biri JRC=5 diğeri ise JRC $=8$ için depremli koşullarda duraylılık analizi.

Figure 23. Stability analysis of wedge sliding at northern side of the western slope based upon a) JRC=5 for both faces, and b) $J R C=5$ for one face and $J R C=8$ for other face under dynamic conditions induced by earthquake.

$\begin{array}{ccc}\text { Güney kanat düzlemsel kaymalar } & \text { ky } \\ \text { için kinematik anlamda duraysızlık }\end{array}$ beklenmemektedir. Kama tipi kaymalar için yapılan kinematik analizlerde, riskli bölgeye düşen kesişme noktaları için duraylılık analizleri yapılmıştır. $\mathrm{Bu}$ analizlerde güney kanat şevlerinin eğim açısı/eğim yönü değerleri için planlanan (65/034) ve düzlemsel kaymaların kinematik analizlerine göre önerilen (65/015) şev konumları dikkate alınmıştır. Yapılan duraylılık analizlerinde en düşük güvenlik katsayısını, her iki şev konumu için de, 1 ve 2 nolu süreksizlikler vermektedir (Şekil 18). Kaymaya neden olabilecek süreksizlikerin pürüzlülük katsayıları $\mathrm{JRC}=5$ için hesaplanan dayanım parametreleri kullanılarak yapılan analizlerde ise güvenlik katsayısı $\mathrm{F}=1.18$ olarak hesaplanmıştır (Şekil 24a, Çizelge 3). Herhangi bir kanat için JRC
$=8$ 'e göre hesaplanan dayanım parametresi kullanıldığında ise güvenlik katsayısı $\mathrm{F}=1.54$ olmaktadır (Şekil 24b, Çizelge 3). Depremli koşulda yapılan duraylık analizlerinde ise güvenlik katsayıları sırasıyla 0.83 ve 1.12 olarak elde edilmektedir (Şekil 25, Çizelge 3).

Bat1 şevlerinde süreksizliklerin pürüzlülük katsayıları (JRC) ortalama 8 olarak bulunduğundan, kuzey ve güney kanat şevlerinde, basamak şev açılarının $65^{\circ}$ olması durumunda statik koşullarda düzlemsel ve kama tipi kaymaların gelişmesi öngörülmemektedir (Çizelge 3). Süreksizliklerin pürüzlülük katsayılarının azaldığı bölgelerde lokal olarak düzlemsel kayma potansiyeli bulunmaktadır. $\mathrm{Bu}$ durum bozunma derecesinin W3-W4 olduğu bölgelerde daha da artmaktadır. 
(a)

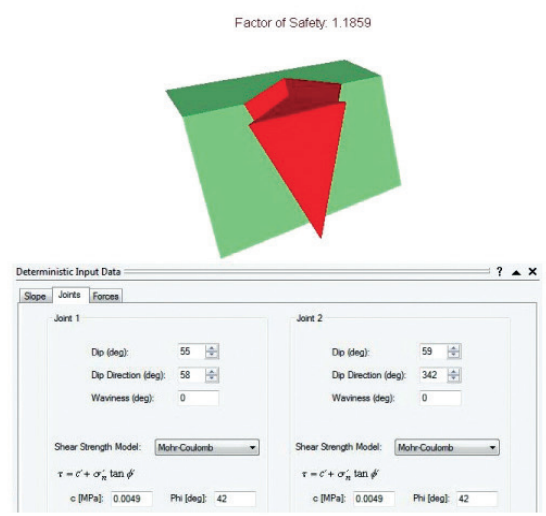

(D)

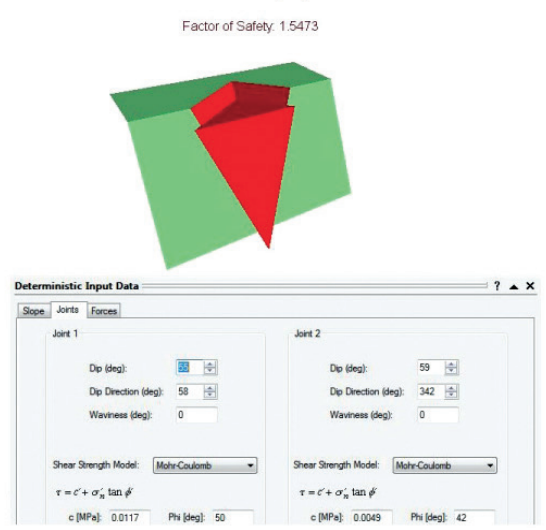

Şekil 24. Güney kanat şevlerinin kama tipi kaymalarda a) her iki yüzey JRC $=5$ için, b) yüzeylerden biri JRC $=5$ diğeri ise JRC $=8$ için statik koşullarda duraylılık analizi.

Figure 24. Stability analysis of wedge sliding at southern side of the western slope based upon a) JRC= 5 for both faces, and b) $J R C=5$ for one face and $J R C=8$ for other face under static conditions.

(a)

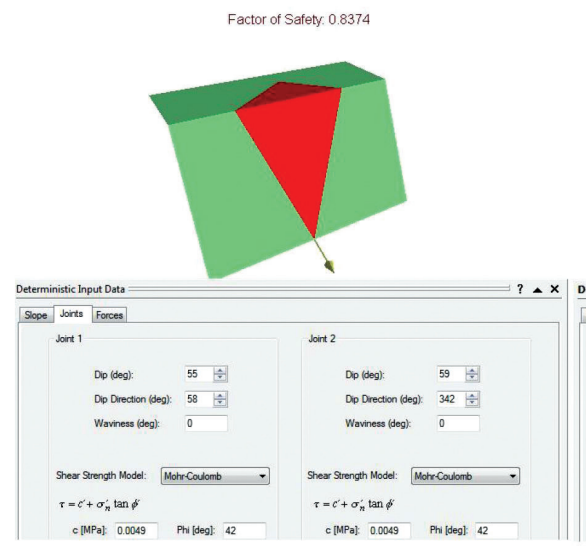

(b)

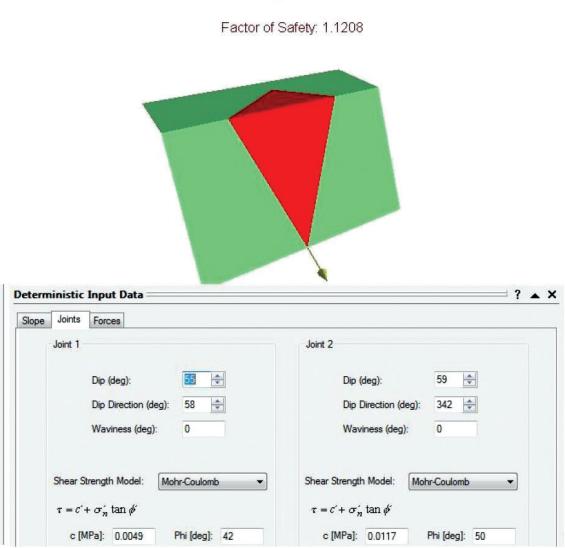

Şekil 25. Güney kanat şevlerinin kama tipi kaymalarda a) her iki yüzey JRC $=5$ için, b) yüzeylerden biri JRC $=5$ diğeri ise JRC $=8$ için depremli koşullarda duraylılık analizi.

Figure 25. Stability analysis of wedge sliding at southern side of the western slope based upon a) JRC=5 for both faces, and b) $J R C=5$ for one face and $J R C=8$ for other face under dynamic conditions induced by earthquake.

Sonuç olarak, Doğu Ocak batı şevlerinin kuzey kanadında düzlemsel kaymalar, basamak şev açıları, W3 bozunma zonunda $65^{\circ}$, W3-W4 bozunma zonunda ise $60^{\circ}$ olması koşullarında engellenebilecektir. Güney kanatta ise kinematik olarak düzlemsel kayma potansiyeli olmamakla birlikte, bozunma kuzey kanada göre daha fazla olduğundan, basamak şev açılarının kuzey kanat için önerilenlerle aynı olması önerilir. Kama türü kaymalar için statik koşuları dikkate alan duraylılık analizlerinde ise $\mathrm{F}>1.3$ çıkmaktadır. Dinamik koşullarda yapılan duraylılık 
Çağlan, Tosun, Avcı, Turunç, Kanaat

analizlerinde ise, W3-W4 bozunma zonunda güvenlik katsayılarıhemen hemen tüm duraysızlık türleri için $\mathrm{F} \leq 1.00$ çıkmaktadır. Ancak, yapılan planlamalara göre, işletme ömrünün yaklaşık 10 y1l olması ve herhangi bir deprem durumunda da ocakta sadece basamak bazında duraysızlıkların gelişebileceği (derin kaymaların beklenmediği) tahmin edildiğinden, ocak şevlerinin statik koşullara göre tasarlanmasının uygun olduğu sonucuna varılmıştır.

\section{SONUÇLAR}

Araziçalışmalarıveyapılandeğerlendirmeler sonucunda, dolgusuz süreksizlik yüzeylerinin dayanım parametrelerinin belirlenmesinde, Bartongörgülyenilmeölçütününkullanılabileceği sonucuna varılmıştır.

Arazi gözlemleri, kinematik ve limit denge şev duraylılık analizi çalışmaları sonucunda; şevlerin eğim yönlerinin batı şevleri kuzey kanadında $218^{\circ}$, güney kanadında ise $15^{\circ}$ olarak açılması önerilmiştir. Güney kanat şevleri için yapılan analizlerde $65^{\circ}$ ' den daha yüksek basamak şev açıları ile çalışılabileceği belirlenmiştir. Ancak, güney kanat şevlerinde bozunma oranının kuzey kanada göre daha fazla olmasından dolay1, her iki kanatta da basamak şev açılarının; W3 bozunma bölgelerinde $65^{\circ}$, W3-W4 bozunma bölgelerinde ise $60^{\circ}$ ile açılması önerilmiştir. Ayrıca, basamak genişliklerinin yapılan planlara uygun olarak $6.0 \mathrm{~m}$ olarak açılmasında bir sakınca görülmemektedir. Şevlerin oluşturulması sırasında ve sonrasında, bir veya birkaç basamağ 1 kapsayacak olası yersel duraysızlıklara dikkat edilmesi gerektiği sonucuna varılmıştır.

\section{KAYNAKLAR}

Barton, N., Choubey, V., 1977. The shear strength of rock joints in theory and practice. Rock Mechanics, 10, 1-54.

Barton, N., 1973. Review of a new shear-strength criterion for rock joints. Engineering Geology, 7 (4), 287-332.

Deprem Araştırma Dairesi Başkanlığı, 1996. Türkiye Deprem Bölgeleri Haritası.

Emre, Ö., Doğan, A., Yıldırım, C., 2012. Biga Yarımadası'nın diri fayları ve deprem potansiyeli. (editör: E. Yüzer, G. Tunay). Biga Yarımadasının Genel ve Ekonomik Jeolojisi, 28, 63-191.

Golder Assocates, 1979. Instruction Manual-I: Geotechnical Data Collection. UNDP Training Project, Contact No: Con. 97/78, 56 s (yayımlanmamış)

Güler, E., Ceryan, Ş., 2015. Burhaniye (Balıkesir) yerleşim alanının sıvılaşma potansiyelinin değerlendirilmesi. Yerbilimleri Dergisi, 36 (2), 81-96.

Herece, E., 1985. The Yenice-Gonen earthquake of 1953 and some examples of recent tectonic events in the Biga Peninsula of northwest Turkey: a thesis in geology. Penn State Universty.

Hoek, E., Bray, J.W., 1981. Rock Slope Engineering. 3rd edition. London, Institute of Mining and Metallurgy. 358-402 p.

ISRM, 1981. Rock characterization, testing and monitoring. International Society for Rock Mechanics Suggested Methods. Pergamon, Oxford. 211 p.

Lisle, R. J., 2004. Calculation of the daylight envelope for plane failure of rock slopes. Geotechnique, 54 (4), 279-280.

MTA, 2012. Maden Tetkik ve Arama Genel Müdürlüğü, Türkiye. http://yerbilimleri.mta.gov. tr/anasayfa.aspx, son erişim 15.05.2015. 
Rocsicence, 2015a. Dips, V. 6.0, Graphical and Statistical Analysis of Orientation Data, Rocscience Inc. Canada.

Rocscience, 2015b. Plane, V.3.0, Planar Sliding Stability Analysis For Rock Slopes, Rocscience Inc. Canada.

Rocscience, 2015c. Swedge, V.6.0, 3D Surface Wedge Analysis For Slope, Rocscience Inc. Canada.

Sarı, R., Tufan, E.A., Yenigün, K.G., 2010. Kentimizin heyelan, deprem ve taşkın alanları açısından irdelenmesi. Balıkesir Kent Sempozyumu
Bildiriler Kitabı, EMO Yayın No: SK/2011/3, Balıkesir, 139-150.

Ulusay, R., Sönmez, H., 2007. Kaya Kütlelerinin Mühendislik Özellikleri. TMMOB Jeoloji Mühendisleri Odası Yayın No: 60, Ankara

Yılmazer, E., Güleç, N., Kuşcu, İ., Lentz, D. R. 2014. Geology, geochemistry, and geochronology of $\mathrm{Fe}$ oxide $\mathrm{Cu}( \pm \mathrm{Au})$ mineralization associated with Şamlı pluton, western Turkey. Ore Geology Reviews, 57, 191-215. 
